\title{
New occurrences of fossilized feathers: systematics and taphonomy of the Santana Formation of the Araripe Basin (Cretaceous), NE, Brazil
}

Gustavo M. E. M. Prado, Luiz Eduardo Anelli, Setembrino Petri, Guilherme Raffaeli Romero

Here we describe three fossil feathers from the Early Cretaceous Santana Formation of the Araripe Basin, Brazil. Feathers are the most complex multiform vertebrate integuments; they perform different functions, occurring in both avian and non-avian dinosaurs. Despite their rarity, fossil feathers have been found across the world. Most of the Brazilian feather fossil record comes from the Santana Formation. This formation is composed of two members: Crato (lake) and Romualdo (lagoon); both of which are predominantly reduced deposits, precluding bottom dwelling organisms, resulting in exceptional preservation of the fossils. Despite arid and hot conditions during the Cretaceous, life teemed in the adjacency of this paleolake. Feathered non-avian dinosaurs have not yet been described from the Crato Member, even though there are suggestions of their presence in nearby basins. Our description of the three feathers from the Crato laminated limestone reveals that, despite the small sample size, they can be referred to coelurosaurian theropods. Moreover, based on comparisons with extant feather morphotypes they can be identified as one contour feather and two downy feathers. Despite their rareness and low taxonomic potential, fossilized feathers can offer insights about the paleobiology of its owners and the paleoecology of the Araripe Basin. 
NEW OCCURRENCES OF FOSSILIZED FEATHERS: SYSTEMATICS AND TAPHONOMY OF THE SANTANA FORMATION OF THE ARARIPE BASIN

\section{(CRETACEOUS), NE, BRAZIL}

\begin{abstract}
Here we describe three fossil feathers from the Early Cretaceous Santana Formation of the Araripe Basin, Brazil. Feathers are the most complex multiform vertebrate integuments; they perform different functions, occurring in both avian and non-avian dinosaurs. Despite their rarity, fossil feathers have been found across the world. Most of the Brazilian feather fossil record comes from the Santana Formation. This formation is composed of two members: Crato (lake) and Romualdo (lagoon); both of which are predominantly reduced deposits, precluding bottom dwelling organisms, resulting in exceptional preservation of the fossils. Despite arid and hot conditions during the Cretaceous, life teemed in the adjacency of this paleolake. Feathered non-avian dinosaurs have not yet been described from the Crato Member, even though there are suggestions of their presence in nearby basins. Our description of the three feathers from the Crato laminated limestone reveals that, despite the small sample size, they can be referred to coelurosaurian theropods. Moreover, based on comparisons with extant feather morphotypes they can be identified as one contour feather and two downy feathers. Despite their rareness and low taxonomic potential, fossilized feathers can offer insights about the paleobiology of its owners and the paleoecology of the Araripe Basin.
\end{abstract}

Keywords: Fossil Feathers, Santana Formation, Systematic Paleontology

* Corresponding author 
37

\section{INTRODUCTION}

Feathers are the most complex integuments of vertebrates, due to their variety of forms and roles. This structure is responsible for the thermoregulation, display, protection against radiation, toxicity, buoyancy and even to produce sound (Lucas \& Stettemheim, 1972; Dumbacher et al., 2004; Bostwick \& Prum, 2005; Clark et al., 2011; Dimond et al., 2011).

Recent molecular studies of feathers suggest a possible phylogenetic hierarchy in the emergence of these elements, connected with the genesis of the tetrapod integuments. During transition from water to land many amphibians shared the same toolkit for coping with environmental changes (e.g. free $\mathrm{O}_{2}$, radiation). On the other hand, reptiles synthesized $\beta$-keratin and mammals, $\alpha$-keratin. Evidence indicates a plausible multiple origin of these structures within Dinosauria (Clarke, 2013), it is possible that the first feathers were present even in the base of the superorder (Xu, 2006; Norell, 2011; Godefroit et al., 2014). Nevertheless, the presence of these elements in basal dinosaurs remains uncertain (Barret et al., 2015). Despite its earliest origin, it was only in maniraptoriformes that "modern-type feathers" (plumulaceous and pennaceous feathers) have arisen (Xu \& Guo, 2009; Clarke, 2013; Godefroit et al., 2013; Han et al., 2014; Koschowitz et al., 2014).

Regardless, the current idea that feathers may not be a plesiomorphic trait in Dinosauria, and pterosaur pycnofibers may not represent true protofeathers (Barret et al., 2015), the filaments were reported in a basal ornithischian (Godefroit et al., 2014). Despite being highly contentious, a possible occurrence of filament-feathers in dinosauromorphs (e.g., Lagerpetidae), or even in early members of saurischia clade (e.g., Herrerasaurids), may fills the possible gap between dinosaurs and ornithodirans. However, remains of these animals are often fragmented or unearthed in coarse grain sediments (Nesbitt et al., 2013; Langer et al., 2013; Benton et al., 2014) that preclude the preservation of these fragile structures. However, both filament and true feathers were reported in Jurassic theropods (megalosauroids and coelurosaurs), suggesting that this character may be present early in theropods (Rauhut et al., 2012; Foth et al., 2014; Xu et al., 2014). Despite the broad distribution within this clade, "true feathers" undoubtedly made of $\beta$ keratin, only started to be synthesized later, in derived theropod dinosaurs, such as coelurosaurs (Prum \& Brush, 2002; Fucheng et al., 2006; Xu, 2006; Xu \& Guo, 2009; Norell, 2011; Clarke, 2013). 
67

68

69

70

71

72

73

74

75

76

77

78

79

80

81

82

83

84

85

86

87

88

89

90

91

92

93

94

95

96

97

Feathers were always thought to be associated with flight (Feduccia, 1993; Martin, 1998). Recent authors (Dial, 2003; Dial et al., 2008; Heers \& Dial, 2012) demonstrated a disconnection between feather and flight. In addition, evidence in non-avian dinosaurs, such as the dromaeosaurids (Han et al., 2014), oviraptorosaurians (Qiang et al., 1998; Xu et al., 2010), ornithomimids (Zelenistky et al., 2012), or tyrannosauroids (Xu et al., 2012) makes this hypothesis even more unlikely. Other controversial interpretations consider that feathers originated to perform the thermoregulation functions (D'Emic, 2015; Myhvold, 2015).

Recent studies indicate that dinosaurs were possibly mesothermic, suggesting no relation with the advent of homeothermy (Grady et al., 2014; 2015). Furthermore, the endothermy may have originated only during or briefly after the advent of flight, since this activity require high metabolism, with high consumption of $\mathrm{O}_{2}$ and a low accumulation of $\mathrm{C}_{3} \mathrm{H}_{6} \mathrm{O}_{3}$ (lactic acid). Whether analogous or homologous, thermoregulation control may have evolved with the help of integumentary coverings (pycnofibers and feathers), and these elements are suggestive of an ornithodiran wide trait, even though this is highly polemic (Unwin \& Bakhurina, 1994; Unwin, 1998; Ruben \& Jones, 2000).

2

33
proposed by Persons \& Currie (2015). According to these authors, beyond its hygienic roles, this hypothesis can satisfactorily explain the origin of filamentous-type integuments that could be located in the face of its owners for semi-fossorial habits. Because the preservation of these elements is unusual in the fossil record, their proposal must require further evidence.

Another reason for the rise of feathers may be the ability to maintain a social relationship between individuals, as extant birds currently do today. It also explains the evolution of the morphotypes, and the wide range of color patterns which have been arisen in avian-dinosaurs, once the sexual selection could be the main driver for their evolution (Dimond et al., 2011; Koschowitz et al., 2014)

2 Because feathers

3 process that follow their burial. Thus, they are usually found as: (i) carbonized and iron traces, 94 (ii) inclusions in ambers and coprolites, (iii) and as imprints (Wetmore, 1943; Martins-Neto \& 5 Kellner, 1988; Davis \& Briggs, 1995; Vinther et al., 2008; McKellar et al., 2011; Vitek et al., $62013)$. 
98 (Kellner, 2002). Despite their rareness, there is a relatively cosmopolitan distribution of these

99 structures, extending from the Middle Jurassic to the Neogene. Feathers were found in Mesozoic 100 and Cenozoic deposits and ambers, in Europe and North America (Kellner, 2002; McKellar et 101 al., 2011; Valentin et al., 2014). On the Southern Hemisphere, they were found in Australia 102 (Talent et al., 1966; Waldman, 1970), and South America (Kellner, 2002; Sayão \& Uejima, 103 2009; Clarke et al., 2010; Leite \& Hessel, 2011; Sayão et al., 2011; Mansilla et al., 2013; 104 Carvalho et al., 2015a; 2015b).

105 The first occurrence of fossil feathers in Brazil was reported from the Oligocene shales of 106 the Tremembé Formation, Taubaté Basin (Shufeldt, 1916), followed by discoveries in other two 107 geologic units: the Aptian-Albian limestones of the Santana Formation of the Araripe Basin 108 (Kellner, 2002; Sayão \& Uejima, 2009; Leite \& Hessel, 2011; Sayão et al., 2011) and Miocene limestones of the Pirabas Formation of the Barreirinhas Basin discovered by Ackerman (1964).

110 While the Pirabas Formation exhibited a single occurrence of feathers since 1964, both Santana 111 and Tremembé formations are responsible for the major records of this type of fossil (Kellner, 112 2002) (Table 1).

113 The fauna of Crato and Romualdo members are probably allochtonous. The diversified 114 biota was seemingly laid down in nearby paleolake shorelines (Naish et al., 2004). A swift 115 deposition in Crato must be responsible for the good preservation of the fossils. However, the 116 presence of the vertebrate remains in Romualdo is often explained by the "drifting hypothesis" 117 proposed by Naish et al. (2004): Carcasses might have been transported by rivers for up to tens 118 of kilometers before reaching the calm waters of the Romualdo lagoon. Once there, they were 119 preserved by the process of 'encapsulation', also known as "The Medusa effect" (Martill, 1989). 120 The Romualdo was characterized by the maximum marine transgression, and salty waters 121 entered this basin in an N-NW direction (Assine, 1994). Therefore, the carcasses of these 122 animals may have been dragged in at water. The drifting hypothesis is also able to explain the 123 preservation of the isolated and often disarticulated bones of pterosaurs, dinosaurs and other 124 aerial and terrestrial vertebrates. Nonetheless, the absence of ichnofossils in the rocks of this unit 125 requires further investigations. Although highly contentious, two other hypotheses may explain 126 the presence of terrestrial vertebrates in the Araripe Basin. Mass mortality events caused by 127 environmental changes (e.g., chemoclinal alterations, remobilization of the anoxic layers) could 128 expose remains of aquatic animals on the shores of the paleolake, attracting animals in order to 
129 prey, where they may have become stuck in the soft and deep sediments (Olson \& Alvarenga, 130 2002, Varricchio et al., 2008). The third hypothesis is based on bacteria Clostridium botulinum, 131 responsible for mass mortality of aquatic birds (Duncan \& Jensen, 1976; Varricchio, 1995).

132 However, these events are restricted to fishes, requiring further evidences of this phenomenon, 133 such as high bone concentration of different vertebrates in the same strata (Varricchio, 1995; 134 Martill, 1997; Martill et al., 2008a).

135 On this paper, we report three new occurrences of fossil feathers, from Cretaceous of 136 Crato Member of the Araripe Basin and propose a systematic approach to these fossils, 137 according to the available data. Preliminary discussions about the taphonomy and paleoecology 138 are presented; the presence of avian dinosaurs and their paleoecology are also discussed.

\section{Geologic Setting}

141 The Araripe Basin (Fig. 1) is located in the northeastern Brazil between longitude $14238^{\circ} 30^{\prime} \mathrm{W}$ to $40^{\circ} 50^{\prime} \mathrm{W}$, and latitude $7^{\circ} .05^{\prime} \mathrm{S}$ to $7^{\circ} 50^{\prime} \mathrm{S}$ (Coimbra et al., 2002; Vianna \& Neumann, 143 2002), and extends approximately 5.500 to $8.000 \mathrm{Km}^{2}$ across three states (Ceará, Pernambuco 144 and Piauí). The exceptional fossil preservation of the Crato Member was highlighted by Martill 145 et al. (2007a), who placed it in a Konservat-Lagerstätte. The geology of this basin has been 146 studied since the 19th century (Carvalho \& Santos, 2005), with differemt interpretations 147 (Maisey, 1991; Assine, 1992; Martill, 1993; Vianna \& Neumann, 2002, Carvalho \& Santos, 148 2005; Assine, 2007; Martill et al., 2007a).

149 Assine $(1992 ; 1994 ; 2007)$ surveyed in detail the entire basin, establishing a stratigraphic 150 subdivision, based on the recommendations of the Brazilian Code of Stratigraphy Nomenclature.

151 This classification is herein followed. The Santana Formation is subdivided into the Crato 152 Member (base), and the Romualdo Member. These units have different lithologies that reflect 153 their distinct depositional environments. Many of the exquisitely preserved fossils of the Araripe 154 Basin come from the Crato Member strata, which is characterized by micritic laminated 155 limestones intercalated with shales and mudstones of varied thicknesses. The unit was formed in 156 a lacustrine environment with brackish water of dubious depth, and reducing conditions in the 157 bottom (Assine, 1992; 1994; 2007; Martill, 2007a; Heimhofer et al., 2010).

158 Since the studied specimens were the product of apprehension (illegal fossil trade), it was 159 not possible to get their stratigraphic positions. However, the laminated limestones (LL) of the 
160 Crato Member, are well known worldwide by geologists and paleontologists. Since the LL only

161 occur in this unit, it was possible to assign these fossils to this specific layer.

162 Santana Formation ostracods and palynomorphs were studied by Coimbra et al. (2002),

163 but only the palynomorphs were fitted for biostratigraphy correlations with nearby basins. Crato

164 is Aptian in age $(\sim 120 \mathrm{Ma})$ and Romualdo is Albian $(\sim 111 \mathrm{Ma})$.

165

166

MATERIALS AND METHODS

167

168

Three specimens were studied and described, following the terminology of Lucas \& Stettemhein (1972); Sick (1984) and Proctor \& Lynch (1993). These fossils were apprehended by the Brazilian Federal Police and the IPHAN (Institute of National Historical and Artistic Heritage) and are deposited in the Paleontological Collection of the Laboratory of Systematic Paleontology from the Institute of Geosciences, of the University of São Paulo, in the city of São Paulo. The specimens received the registered numbers: GP/2E-7853, GP/2E-7854 and GP/2E8771. The acronyms used in the collection assign the "GP" to Geology and Paleontology sets, and ' $2 \mathrm{E}$ ', to the vertebrate set.

All specimens were photographed using a millimeter-scale stand with Canon EOS REBEL T3 with aperture of $100 \mathrm{~mm}$ and under a stereomicroscope Carl Zeiss with a capture system AxioCam ICC3 and using the AxioVision LE software. The specimens were measured with a caliper and the AxioVision LE software. Specific portions of the feathers, such as barbs and rachis were measured. The difference between every portion (i.e., calamus, larger barb, used to infer the morphology and to classify them according to the terminology of extant feathers (Lucas \& Stettemheim, 1972; Sick, 1984; Proctor \& Lynch, 1994).

\section{RESULTS}

186 
191

192

193

194

195

196

197

198

199

200

201

202

203

204

205

206

207

208

209

210 211 2010).

212 Diagnosis: Despite a fairly generic morphotype, this specimen has typical plumulaceous feather

213

214

215

216

217

218

219

220

221
Division Coelurosauria Von Huene 1914 sensu Gauthier 1986

Family Incertae sedis

(Figure 2, B - C)
Material: GP/2E-7853 (Fig. 2, C).

Horizon: Crato Member, Santana Formation, Araripe Basin.

Lithology: Weathered (beige) micritic laminated limestone.

Age: Lower Cretaceous (Aptian).

Description: This specimen is a complete feather with reduced dimensions compared to other morphotypes (i.e., contour feathers and pennaceous feathers) where it is possible to see the sizes and differences (Tables 2 and 3). It presents an orange coloration. Barbules are not clearly visible and are presented only in some regions of the barbs. The rachis consists of a thin line. The distal extremity presents ramifications, where barbs with different length originate. As well as in other feathers, the calamus was not preserved. It may represent the morphotype "IIIb" of Prum \& Brush (2002) evolutionary model, and by its morphology it can be associated to plumulaceous feathers where rachises are generally thin and barbs are open vaned.

Measures: See table 2, first row. Dimensions are in $\mathrm{mm}$.

Taphonomy: The color of this specimen (orange/reddish), suggests that the fossil may be preserved as an iron oxide. The matrix light beige color may be the result of slight weathering, calcified filaments and dendritic crystals of sphalerite (Martill \& Davis, 2001; Heimhofer et al., morphology due to the presence of very well delineated rachis and barbs of varying sizes. The rachis is $8.27 \%$ longer than the larger barb. Since GP/2E-7853 has a longer rachis than the largest barbs, and fluffy aspect, dimension, and morphology, this feather is assigned as a downy feather (Lucas \& Stettemhein, 1972; Sick, 1984; Proctor \& Lynch, 1994). It is not possible to observe the presence of the calamus. Generally, because of their fragility and small size (in life it may represent only $1.5 \%$ of the total length of the feather), this portion, commonly, does not preserve in the fossil record (Lucas \& Stettenheim, 1972; Kellner, 2002). In the sample matrix, a nearly complete skeleton of a small fish is associated (Fig. 2, H-I), classified as Dastilbe sp. (Maisey, 1991; Dietze, 2007; Martill et al., 2007a). 
222

223

Family Incertae sedis

224

225 Material: GP/2E-7854 (Fig. 2, B).

226 Horizon: Crato Member, Santana Formation, Araripe Basin.

227 Lithology: Weathered (beige) micritic laminated limestone.

228 Age: Lower Cretaceous (Aptian).

229 Description: The proximal portion is degraded, though, the rachises arevisible. Several barbs 230 with different length originate from them. It is also possible to notice the presence of vestigial

231 barbules (Fig. 2, E). The calamus is a slight line, and together with GP/2E-7853, this feather can 232 also be assigned to "IIIb morphotype (Prum \& Brush, 2002).

233 Measures: See table 2, second row. Dimensions in $\mathrm{mm}$.

234 Taphonomy: Similar to GP/2E-7853, this sample is a small feather, but complete. The color 235 varies from between the proximal to distal portion of the vanes, among lighter to darker 236 brownish tones, as a consequence of different preservation in carbonaceous traces (Davis \& 237 Briggs, 1995).

238 Diagnosis: This specimen also presents the typical morphology of the plumulaceous feathers, 239 classified as downy feathers. On the umbilicus proximallis portion (Fig. 2, F-G), the slight line 240 structure consisted of an external molt that is interpreted as the vestige of the calamus. By the 241 preservational characteristics (e.g., external mould, lack of organic remains), the evidence 242 suggests that this portion was degraded during the taphocenosis, or geochemical processes that 243 followed the burial (diagenesis). In GP/2E -7854the difference between the rachis and the 244 longest barbs of $\mathrm{GP} / 2 \mathrm{E}-7854$ is $48.21 \%$. Division Coelurosauria Von Huene 1914 sensu Gauthier 1986 
253 Material: GP/2E-8771 (Fig. 2, A).

254 Horizon: Crato Member, Santana Formation, Araripe Basin.

255 Lithology: Grayish micritic laminated limestone.

256 Age: Lower Cretaceous (Aptian).

257 Description: This specimen is a complete feather and the largest of the three, compared with the 258 two previously described (tables 2 and 3). Different barbs with variable lengths originate from a 259 slight rachis. The barbules are clearly visible (Fig. 2, D), and vary in size. In extant feathers, 260 vanes are united by the 'hooklets' (structures similar to hooks) (Lucas \& Stettenheim, 1972; Sick, 261 1984), but hooklets are not preserved.

262 Measures: See table 2, third row. Dimensions are in $\mathrm{mm}$.

263 Taphonomy: This specimen, like GP/2E-7853 and GP/2E-7854, also occurs in a limestone 264 matrix.

265 Due to the blackish color of the fossil, this feather possible was preserved as carbonized trace, 266 since it is the common type of preservation (Davis \& Briggs, 1995).

267 Diagnosis: According to morphology, GP/2E-8771 is associated to the typical extant contour 268 feathers or semiplumes. Attached to the basal part (the umbilicus), structure reminding 269 afterfeather emerged, forming a V shape, larger than the vanes (Lucas \& Stettenheim, 1972). 270 However it does not exbit afterfeather diagnose features, like "slight rachis" or umbilical origin.

271 The barbules are present suggesting some degree of cohesion between barbs. However no 272 'hooklets' (barbicels) are preserved on this specimen. The characteristic that distinguish this 273 specimen from the other two previously described is the hue color of the matrix. This feature is 274 suggestive that this sediment was not exposed to weathering processes which usually change the 275 rock color (Martill \& Frey, 1995). In an attempt to turn the fossils more attractive, some portions 276 of the feather were degraded with a scraper tool by the illegal dealers, especially on the portion 277 where the calamus was supposed to be found. The GP/2E-8771 is the only Mesozoic feather 278 described here that could be assigned to the crown group Aves, since all of its characteristics are 279 very similar to modern morphotypes. However, because this morphotype were also found in non280 avian dinosaurs, a parsimonious assignment is that it belonged to the maniraptoran clade. The 281 specimens possess a morphotype similar to semiplumes, with an apparent aftershaft on the 282 proximallis portion. However, this structure may not represent the semiplume. The rachis is $28343.95 \%$ shorter than the longest barb. The morphology of this feather is similar to the type of 
284 afterfeathers that possess a long, narrow rachis with shorter vanes. The hyporachis is almost the 285 same length of the afterfeather. In extant cases, these feathers are related to birds of Galliformes, 286 Tinamiformes and Trogoniformes orders (Lucas \& Stettenheim, 1972).

287

\section{DISCUSSION}

289

290

291

292 different from fish scales, mollusks shells, plant trunks and leaves, none of them, to date, have received a proper taxonomic treatment. The main reason for the lack of systematic (taxonomic) procedure may be caused by their scarcity and common occurrence as isolated feathers which hamper taxonomic assignment. However, it does not prevent other systematics works from being performed. Despite the taphonomic significance, this perfunctory treatment can also be an issue that systematists simply ignore, once these elements demonstrate low taxonomic interest (i.e., low potential to assign a new taxon). Nevertheless, the characteristics of a feather also allow its recognition as part of family or subfamily. Rautian (1978) applied a different taxonomic approach to these elements, once their existence represented (at that time) a diagnostic feature of a new bird taxon. Nowadays, this method proves to be problematic, since non-avian dinosaurs also possessed them, demanding a different way to assess their taxonomic value. Williamson et al. (2009) applied a systematic procedure, which is very similar to the present paper, to describe feathers from the Upper Cretaceous of New Mexico. However, their approach was superficial and brief, attending only to geological features without any other information such as taphonomy and paleobiology. Their description failed to explain and support the taxonomic assignment attributed by these authors. The approach we propose is a simple and parsimonious approach to describe fossilized feathers, assigning their morphotypes to the basal animals that possessed them according to the fossil record of non-avian and avian dinosaurs.

Based on the morphology (barbs that originates from a scanty rachis; absence of barbules; small dimension between morphotypes; bigger length of the barb than the rachis; and,

311 fluffy aspect), and comparison of the specific portions (table 3) of the three feathers, it was 312 possible to classify these feathers to plumulaceous and pennaceous morphotypes (table 4). The

313 occurrence of these morphotypes are wide in the extant class Aves, once they are present beyond 314 the semiplumes and are located in the apterium portions of most birds (Lucas \& Stettenheim, 
315 1972). According to the fossil record, these structures could also belong to non-avian dinosaurs,

316 making the taxonomic assignment even harder to be inferred (Prum \& Brush, 2002; Fucheng et

317 al., 2006; Xu \& Guo, 2009). Moreover, since all specimens are from the Mesozoic (period

318 marked by "evolutionary experiments"), at least two specimens (GP/2E-7853 and GP/2E7854)

319 deserved more attention by their generic morphotypes, which resemble, ontogenetically, early

320 and evolutionarily basal feathers. Despite the controversy over morphotype diversity provided by

321 the squeeze effect diagenesis (Foth, 2012) and, with the apparent decrease of species suggested

322 by the fossil record (Fucheng et al., 2006; Xu \& Guo, 2009; Xu et al., 2010), it was possible to

323 associate both specimens aforementioned to their evolutionary stages, as it was proposed by the

324 literature (Prum and Brush, 2002; Xu \& Guo, 2009).

325 The preservation of the macro-structures and identification of morphotype and size, allow

326 suggestions into the possible roles of feathers during life, their placement throughout their body,

327 and proportions of the owners (Lucas \& Stettemheim, 1972; Sick, 1984; Proctor \& Lynch, 1993).

328 According to Lucas \& Stettenheim (1972), both feathers have the morphotype, size (length

329 between 2.5 to $17 \mathrm{~mm}$ ) and general aspects similar to auricular feathers. Regardless the

330 ontogenetic possibilities (Xu et al., 2010; Zelenitsky et al., 2012), which are difficult to be

331 inferred by isolated feathers, the parsimonious explanation is that they represent adult forms. If

332 this identification is correct, the animal that possessed these elements may not have had large

333 dimensions, i.e., not exceeding the size of a domesticated chicken (Lucas \& Stettenheim, 1972).

334 The fact that a small sized euenantiornithe was found in this deposit, as well as many other small

335 isolated feathers (the larger measured, is $85 \times 11 \mathrm{~mm}$ ) also corroborate this idea (Kellner, 2002;

336 Sayão et al., 2011; Leite \& Hessel, 2011). Thus, it must have a similar role to the extant birds,

337 where the main function is in ear protection (Lucas \& Stettenheim, 1972). The other feather

338 (GP/2E-8771), a contour feather, was suggested to have also taken the same protective function.

339 However, it might also have functioned in thermoregulation. Nevertheless, even in basal

340 coelurosaurs, they may have had other roles such as display, shielding nests, etc. (Turner et al.,

341 2007). Other lines of evidence suggest that dinosaurs already possessed visual acuity, with

342 nocturnal or crepuscular behavior, and abilities to visually communicate might have been present

343 in the Mesozoic (Varricchio, et al., 2007; Xu et al., 2009; Schmitz \& Motani, 2011; Koschowitz 344 et al., 2014).

345 The morphotype GP/2E-8771, and the position throughout the body, point to the 
346 possibility that this feather might have favored camouflage and communication between its

347 owners, as seen in modern birds (Gluckman \& Cardoso, 2010). In addition, based in extant

348 examples, it could also have assumed a sexual role, similar to extant birds with iridescent and

349 colorful feathers, such as peacocks (Zi et al., 2003) and birds-of-paradise (Irestedt et al., 2009).

350 However, this interpretation is merely speculative, since the true colour and position on the body

351 is uncertain.

352

353

Sedimentary Deposition, Paleoenvironment, and Taphonomy

354

355

The Santana Formation, during the Aptian-Albian, was under two different depositional

356

systems. The Crato deposits were laid down under a restricted lacustrine brackish water

357

environment. The Romualdo deposits, on the other hand, were thought to be formed under a lagoon in seasonal contact with marine waters, or at moments of marine regressiontransgressions (Assine, 1994; 2007; Martill et al., 2007a). An unconformity separates these units; stratas of shales and evaporites that characterizes the 'Ipubi Layers' occur with varied thickness and lateral continuum, suggesting the possible shallowing of the water column (Assine, 2007; Martill et al., 2007b).

According to paleontological and sedimentary evidence, such as palynomorphs and evaporites, the Crato Member was laid down under clear and relatively shallow waters during an arid and dry climate, where the carbonate sediments were deposited in a low energetic input with formation of halite and anhydrite minerals (Assine, 1994; Silva et al., 2003; Assine, 2007; Martill et al., 2007b). As suggested elsewhere (Martill et al., 2007a), this anoxic and hypersaline environment prevented the presence of the bottom-dwelling organisms, so the salinity content might have been higher than the osmotic toleration (Martill, 1993; Martill et al., 2007a, b; Martill et al., 2008b).

The source of Crato calcareous deposits might be stromatolites from the border of the basin (Martill, 1993; Srivastava, 1996), but algal bloom events might also have occurred (Martill et al., 2007a, Martill et al., 2008b). The presence of articulated, undisturbed fossils, and pseudomorphs of pyrite and marcasite, indicate that the reducing conditions prevailed at the bottom of the paleolake, enabling the exquisite preservation of non-resistant tissues (Fielding et al., 2005; Martill et al., 2007a; Pinheiro et al., 2012; Simões et al., 2014; Barling et al., 2015). 
377 The high degree of articulation and the exquisite preservation suggest a low energy environment, 378 without any or significant carcass transportation, as well as disturbance by scavenging organisms 379 (Fielding et al., 2005; Martill et al., 2007a; Báez et al., 2009; Figueiredo \& Kellner, 2009; 380 Pinheiro et al., 2012; Barling et al., 2015).

Despite this "harsh" environment, this unit is remarkable in the abundant biota, preserved with a high degree of fidelity. The vertebrate fauna is composed primarily by crocodiles, turtles, frogs, birds, pterosaurs, and numerous fishes (Maisey, 1991; Martill, 1993; 1997; Fielding et al., 2005; Martill et al., 2007a; Martill et al., 2008a; Figueiredo \& Kellner, 2009; Pinheiro et al., 2012; Simões et al., 2014; Oliveira \& Kellner, 2015). Invertebrate animals were also abundant, with the mainly occurrences of arthropods and mollusks (Maisey, 1991; Martill, 1993; Grimaldi \& Engel, 2005; Martill et al., 2007a; Barling et al., 2015). The flora was also exuberant and diversified (Martill et al., 2007a; 2012; Mohr et al., 2015), characterized by macro and microfossils pteridophytes, gymnosperms, angiosperms, palynomorphs, pollen, seeds, etc. (cf. Maisey, 1991; Martill, 1993; Martill et al., 2007a; 2012). The fauna of the Crato Member may have been autochthonous (Naish et al., 2004), however, the Santana Formation terrestrial vertebrates thrived at different geographical regions through time, indicated by evidence in other adjacent basins (Carvalho \& Gonçalves, 1994; Carvalho, 1995; Carvalho \& Araújo, 1995; Carvalho et al., 1995; Carvalho \& Pedrão, 1998). Nevertheless, in both lagerstätten units (Crato and Romualdo), animals were well adapted to the arid and dry climate (Naish et al., 2004; Martill et al., 2007a; Heimhofer et al., 2010). Many of the animals may have lived in the surroundings of the palaeolake allowing a high diversity of plants, especially angiosperms. At least and especially in the Crato Member, it is possible that birds lived by the shore which enhanced the probability of these elements being preserved, and because of the absence of nonavian dinosaur bones, it is possible that these animals lived inland, off the palaeolake surroundings. This niche occupation pattern would explain the large record of fossil feathers 402 recovered from this unit.

From the three specimens studied, only GP/2E-7853 shows coloration (reddish/orange) that is typical of the iron oxides-hydroxides, possibly limonite. This type of preservation was also observed in other feathers from the same provenance (Maisey, 1991; Martins-Neto \& Kellner, 1988; Martill \& Frey, 1995; Martill \& Davis, 2001). The remaining specimens may be 
408 molecules, with characteristic dark black hue (Tegelaar et al., 1989; Davis \& Briggs, 1995; 409 Kellner, 2002; Briggs, 2003). However, to be sure of this chemical composition further 410 investigations are needed. The process of preservation also explains the absence of hooklets in 411 all specimens, since these structures are very delicate, their presence is not expected, so this 412 feature is not common in preserved feathers in rocks being only present in feathers within amber 413 (Davis \& Briggs, 1995; Laybourne, 1994; Perrichot et al., 2008; Mckellar et al., 2011; Thomas 414 et al., 2014).

415 The main hypothesis that explains the presence of isolated feathers in the fossil record, as 416 is in the Crato, assumes that these elements may have been blown into the paleolake by strong 417 winds events. Once they have reached the lake, these feathers would sink quickly, reaching the 418 bottom in seconds to a few minutes, where they might be rapidly buried (Martill \& Davis, 2001).

419 Birds normally lose their feathers during ontogenetic phases or seasonably. It may also 420 happen under stress conditions when living birds have a tendency to release rectrices and 421 semiplumes (Sick, 1984). Possibly it happens also as the result of predation by aquatic predators, 422 however there is no evidence of this in Crato Member (Davenport, 1979; French, 1981; Perry et 423 al., 2013; O'Brien, 2014). Despite the possibility that birds were also prey, the fossil record of 424 the established trophic chain do not yet show that these animals were a food source for other 425 organisms. Furthermore, coprolites did not yet provide evidence of this diet (Maisey, 1991; 426 Martill, 1993; Lima et al., 2007).

427 The carbonate concretions of the Romualdo Member of the Santana Formation, provided 428 a record of at least four non-avian theropods, with the possibility of a fifth (Machado and Kellner 429 (2007), interpreted as a rib of an unknown theropod. Only theropods were found in this unit so 430 the dinosaur fauna of the Araripe Basin consists of two spinosaurids, Irritator challengeri 431 (Martill et al., 1996) and its possible synonym, Angaturama limai (Kellner \& Campos, 1996); 432 and two coelurosaurs, Santanaraptor placidus (Kellner, 1999) and Mirischia asymmetrica (Naish 433 et al., 2004). The latter two likely had some feathery integument (Ji \& Ji, 1996; Chen et al., 434 1998; Ji et al., 2007). The first Mesozoic record of definitive avian dinosaur in Brazil, was only 435 described recently, a fossil unearthed from the Crato Member of the Santana Formation 436 (Carvalho et al., 2015a, b). The feathers of Cratoavis cearensis (Carvalho et al., 2015b), bare 437 interesting features, such as an extremely long rectrices, secondary remiges, alular feathers, and 438 filamentous feathers. Regarding the remex and rectrices, there is no doubt that they were 
439 pennaceous feathers. Nevertheless, the filamentous elements may be a taphonomic artifact (Foth, 440 2012), these structures most likely were contour feathers or downy feathers. Patches with 441 granulate spots rectrices may be associated with color patterns. However, no other evidence of its 442 hue is given by the authors.

443 Evidence of feathers was not detected in any taxa of non-avian dinosaurs of the Araripe 444 Basin (Kellner, 1999; Naish et al., 2004), event though feathers are considered plesiomorphic 445 features for all taxa recorded here (Rauhut et al., 2012, Godefroit et al., 2013). This absence is 446 odd given the vast record of soft tissues in both members (Crato and Romualdo), such as insect 447 muscle fibers (Grimaldi \& Engel, 2005; Barling et al., 2015), dinosaurs blood vessels (Kellner, 448 1996a), pterosaur wing membranes, muscle fibers, and headcrest (Martill \& Unwin, 1989; 449 Kellner, 1996b; Pinheiro et al., 2012), fish muscle tissue and stomach contents (Martill, 1989; 450 1990; Wilby \& Martill, 1992), skin impressions of turtle (Fielding et al., 2005), fossilized 451 microbodies related to pigmentation (Vinther et al., 2008), among others (cf. Martill, 1993; 452 Martill et al., 2007a).

453 With the exception of Cratoavis cearensis (Carvalho et al., 2015b), feathered non-avian 454 dinosaurs remain unknown in the Crato Member. Also, non-avian dinosaurs found in the 455 Romualdo Member do not show evidence of feathers preserved with bones. Since their absence 456 in both Lagerstätten (Crato and Romualdo) marks an unknown event, some possibilities emerge 457 from it: (i) the non-avian dinosaurs of this deposits were glabrous (i.e., they did not possessed 458 feathers) or were low in coverings; (ii) a selective taphonomic or geological process erased them; 459 (iii) during the time of deposition, taphonomic conditions were very different between both 460 members or even to the same unit, preventing their preservation; (iv) all possibilities may have 461 happened simultaneously, or consecutively for the case of taphonomical and diagenetical 462 processes; or, (v) these animals were not discovered yet. With the exception of the latter and the 463 third, all other possibilities are regarded problematic. Firstly, the non-avian dinosaurs of the 464 Araripe Basin were most likely covered with feathers or filament types, especially because these 465 animals belonged to clades with feathered individuals (Ji \& Ji, 1996; Chen et al., 1998; Ji et al., 466 2007). Secondly, the process of fossilization in both units preserved tissues which are more 467 prone to degradation (e.g., muscles fibers, blood veins), but in the Romualdo Formation it did not 468 allow feathers that are relatively more resistant. It is important to state that analogous deposits 469 with similar lithology (limestone rocks) and depositional settings, e.g., the Las Hoyas Formation 
470 in Spain (Sanz et al., 1988; 1996) and the Solnhofen Formation in Germany (Barthel et al., 471 1994), hold records of dinosaurs preserved similarly to the Araripe Basin. Especially in 472 Solnhofen, feathers are present in the Archaeopteryx specimens, but they are not in the 473 Compsognathus longipes Wagner, 1859 (Barthel et al., 1994) or Juravenator starki (Göhlich \& 474 Chiappe, 1998), suggesting that the third hypothesis may be true, once the selective 475 taphonomic/geological events can determinate the differential preservation of carcasses in the 476 same depositional conditions. Especially to Santana fossils, the formation of concretions of the 477 Romualdo Member may be responsible for obliterating these integumentary tissues since 478 carcasses may have experienced some degree of transport and disarticulation, taken more time to 479 be finally encapsulated. Differently, the Crato Member preserved rapidly and in situ, entire 480 animals and climate may be responsible for the absence of non-avian dinosaurs, since in arid 481 conditions are expected a low diversity of life (Stevens, 1989; Tilkens et al., 2007; Butler \& 482 Barret, 2008). Therefore, is possible to consider that non-avian dinosaurs may have reached the 483 shorelines of the paleolake only occasionally, for food or water.

By their localization throughout the body, the feathers would be exposed to geochemical reactions during the initial phase of decay that followed the burial, being degraded early after exposing weathering or early diagenesis. However, as dinosaur remains were preserved within nodules, weathering is not responsible for the absence of these elements, since the dinosaur tissues remained relatively isolated from the surrounding environment throughout the geological time. It is expected that further studies may enlighten this odd absence.

To date, only a few records of feathers or filaments considered as 'protofeathers', were found associated with ornithischians dinosaurs (Mayr et al., 2002; Xu et al., 2009; Zheng et al., 2009; Saveliev \& Alifanov, 2014; Godefroit et al., 2014). Also, only skin impressions, osteoderms and ossicles of giant ornithischians and sauropods (including juveniles), were 494 reported in the fossil record (Czerkas, 1992; Xu et al., 2001; Coria \& Chiappe, 2007; Christiansen \& Tschopp, 2010; Arbour et al., 2014). In spite of the fact that true feathers were only reported in theropod dinosaurs, the poor record of feathers in ornithischia specimens and their absence in the entire subgroups (e.g., Thyreophora and Ornithopoda), as well as in sauropods, suggest that the preservation of these elements can be assigned to the sedimentological characteristics in which these animals were buried, representing a taphonomic artifact. In spite of occasional events of great sediment deposition, as well as the distribution of 
501 herbivorous dinosaurs over these sedimentary deposits (Butler \& Barrett, 2008), according to 502 extant examples (Behrensmeyer, 1978; 1982), the preservation of their carcass (often huge) 503 required more time to be completely buried.

504 The delay between death and final burial, might explain the absence of feathers alongside 505 sauropods and great ornithischians bones. Furthermore, this slow process of preservation 506 opposes the rapid burial suggested to the Crato Member (Martill \& Davis, 2001). The 507 sedimentary relationship has been examined in detail in dinosaur bearing deposits, such as the 508 Morrison Formation and Judith River Formation of North America (Dodson et al., 1980; Wood 509 et al., 1988), but, to the Araripe Basin, they are based mainly in the fish fauna and restricted only 510 to Romualdo (Martill, 1988; 1989).

511 Even though a recent study demonstrated that lithology itself may not be a sure factor for 512 skin preservation of hadrosaurs (Davis, 2012), it may be an important factor, and perhaps 513 decisive, factor in feather preservation. Another taphonomic feature that has to be considered is 514 the type and grain size of the sediment that buried these animals (Barrett et al., 2015). 515 Siliciclastic coarse grains, tend to preserve only larger hard parts of the animals (i.e., bones, 516 keratinous beaks, tooths, and claws). Generally these sediments are related to high energetic 517 depositional systems, with unidirectional flows, such as rivers and streams (Behrensmeyer, 1982; 518 1988; Holz \& Simões, 2002). Several evidences of Cretaceous enanthionithines and 519 maniraptorans were found in sandstones of tidal, fluvial and flood plain deposits of Paraná Basin 520 and São Luis-Grajaú Basin (Carvalho \& Pedrão, 1998; Alvarenga \& Nava, 2005; Novas et al., 521 2005; Azevedo et al., 2007; Elias et al., 2007; Machado et al., 2008; Candeiro et al., 2012a; $b$; 522 Marsola et al., 2014; Tavares et al., 2014; Delcourt \& Grillo, 2015). However, with the 523 exception of Cratoavis cearensis which was found in the carbonates of the lacustrine Crato 524 Member of Araripe Basin (Carvalho et al., 2015a, b), no other feathered dinosaurs were found in 525 these deposits.

526 According to evidences in other non-avian dinosaurs (Mayr et al., 2002; Xu et al., 2009;

527 Zheng et al., 2009; Godefroit et al., 2014), it is possible that these elements were restricted to 528 some regions of the body, in which they were not favored for preservation. We make here a 529 parsimonious assignment of both feathers, GP/2E-7853 and GP/2E-7854, to the Coelurosauria 530 clade. Because true pennaceous feathers were found in ornithomimosaurs (Zelenitsky et al., 531 2012), we assign GP/2E-8771 to the Maniraptoriformes clade. As pointed out by the large 
532 amount of evidence, both groups are responsible for these integuments in dinosaurs (Clarke, 533 2013).

534

535 Future perspectives

536

537

538

539

540

541

542

543

544

545

546

547

548

549

550

551

552

553

554

555

556

557

558

559

560

561

562

In a striped contour feather from the Araripe Basin described by Martill \& Frey (1995), Vinther et al. (2008) have found oblate microbodies restricted only to the dark portions of the specimen. The light portions were markedly preserved as imprints. Those structures were previously interpreted as autolithified bacteria (Wuttke, 1983; Davis \& Briggs, 1995), but subsequent studies revealed them as evidence of fossilized melanosomes (Zhang et al., 2010; Barden et al., 2014; Li et al., 2014; Egerton et al., 2015; Vinther, 2015; Lindgren et al. 2015a, b). This interpretation, enabled reconstructions of ancient color patterns of extinct animals, such as dinosaurs, birds, reptiles and fishes. (Vinther et al., 2008; 2010; Clarke et al., 2010; Carney et al., 2012; Field et al., 2013; Li et al., 2010, 2012, Lindgren et al., 2012, 2014; 2015a, b). As Vinther et al. (2008) demonstrated fossilized feathers from the Araripe Basin possess great potential in future taphonomical investigations, characterizing its importance in paleobiological studies of Mesozoic deposits.

Further investigations using Scanning Electron Microscopy equipped with Energy Dispersive X-Ray Spectroscopy (SEM-EDS) will help in the identification of the presence of ultrastructures such as minerals, melanosomes, and other possible elements, confirming their preservation as described in the present paper. In addition, other techniques, such as Raman Spectroscopy (RAMAN), X-Ray Fluorescence (XRF), Gas Chromatography-Mass Spectrometry (GC-MS), among others, also may add information such as its chemistry (Wogelius et al., 2011; Egerton et al., 2015), indicating possible taphonomic processes that occurred after deposition (Davis \& Briggs, 1995; Schweitzer et al., 2008; McNamara, 2013).

Besides the study with ancient pigmentation, the application of these techniques are important, providing more information about these fossils, especially from the Araripe Basin, where fossil records of feathered dinosaurs is still limited (one enantiornithine and four nonavian theropods). These approaches not only allow a better understanding of the taphonomic and diagenetic processes that occurred in this basin, but enable future paleoenvironmental and paleoecological reconstructions (Li et al., 2010) 


\section{CONCLUSION}

565

566

Despite the difficulty on the systematic approach, it is possible to identify isolated

567

568

569

570

571

572

573

574

575

576

577

578

579

580

581

582

583

584

585

586

587

588

589

590

591

592

593

feathers of lower taxonomic rank, relying on the fossil record of the unit. For the Santana Formation of the Araripe Basin, the maximum taxonomic status reached is the Division (Coelurosauria) and Subdivision level (Maniraptoriformes). Based on the extinct and modern morphotypes, and on evolutionary models of feathers, the fossils were identified as two downy feathers (GP/2E-7853 and GP/2E-7854) and one semiplume (GP/2E-8771).

Although further geochemical analyses are being done, these feathers may be preserved as limonite $(\mathrm{GP} / 2 \mathrm{E}-7853)$ and carbonized traces $(\mathrm{GP} / 2 \mathrm{E}-7854$ and $\mathrm{GP} / 2 \mathrm{E}-8771)$; and the mechanisms which allowed the preservation of these elements were briefly discussed. As suggested by Martill \& Davis (2001), it is also considered that these feathers have been transported into the paleolake by strong winds. Once in the waters, they sunk and were buried rapidly in the anoxic bottom. The absence of oxygen has an important role, once it prevented the activity of scavenging organisms, allowing its preservation. Nevertheless, other possible causes are also being considered, e.g., by predation (by fright molt).

The presence of avian and non-avian dinosaurs in the Araripe Basin is undeniable. Records of avian dinosaurs in the Crato Member consist of one bird and several isolated feathers, however evidence of non-avian dinosaurs remains unknown. On the other hand, in the Romualdo Member, four non-avian dinosaurs were described, but there are not yet formal descriptions of avian dinosaurs, nor even the presence of feathers associated directly with bones. However, in this unit, soft tissues were found in many animals including non-avian dinosaurs. Although unlikely, it is possible that a differential taphonomic process happened, preserving these nonresistant tissues instead of feathers.

Further geochemical investigations may reveal this process and how these specimens were preserved. Future investigations may also focus on the identification of the ultrastructures in addition to its chemical composition, offering the possible roles in life.

Despite their rareness and low taxonomic potential, fossilized feathers can offer insights about the paleobiology of its owners and the paleoecology of the Araripe Basin. 


\section{ACKNOWLEDGEMENTS}

595

596

597

598

599

600

601

602

603

604

605

606

607

608

609

610

611

612

613

614

615

616

617

618

619

620

621

622

623

624

We are in debt and deeply thankful for Jennifer Watling (University of Exeter and University of São Paulo) for the revision and suggestion made on the manuscript. We also would like to thank Luis Fábio Silveira (Ornithological Collection of the Zoology Museum - University of São Paulo) for the helpful comments and aid on the identification of these specimens. We also thank Ivone C. Gonzales (Institute of Geosciences of University of São Paulo) for the support in the accessing the Paleontological Collection and these specimens. And we are deeply thankful of Gabriel L. Osés (Institute of Geoscience of University of São Paulo), Bruno B. Kerber (Federal University of São Carlos - São Carlos), Cibele G. Voltani (São Paulo State University - Rio Claro), and Mírian L. A. F. Pacheco (Federal University of São Carlos - Sorocaba) with the support and invaluable comments. We thank T. Alexander Dececchi, Natasha Vitek and Mark T. Young for the helpful and invaluable comments on the manuscript.

Additional information: The authors declare no competing financial interests.

\section{REFERENCES}

ACKERMAN FL. 1964. Geologia e fisiografia da região Bragantina (Estado do Pará). Cadernos da Amazônia (INPA), Vol. 2. pp. 1-90.

ALVARENGA HMF. 1988. Ave fóssil (Gruiformes: Rallidae) dos folhelhos da Bacia de Taubaté, Estado de São Paulo, Brasil. An Acad Bras Cienc, Vol. 60 (3):321-328.

ALVARENGA HMF, NAVA WR. 2005. Aves Enantiornithes do Cretáceo Superior da Formação Adamantina do Estado de São Paulo, Brasil. II congresso Latino-Americano de Paleontologia de Vertebrados, Rio de Janeiro, Agosto de 2005. pp. 20.

ARBOUR VM, BURNS ME, BELL PR, CURRIE PJ. 2014. Epidermal and dermal integumentary structures of ankylosaurian dinosaurs. J Morphol, Vol. 275 (1):39-50.

ASSINE ML. 1992. Análise estratigráfica da Bacia do Araripe, Nordeste do Brasil. Rev Bras Geocienc, Vol. 22 (3):289-300.

ASSINE ML. 1994. Paleocorrentes e paleogeografia na Bacia do Araripe, nordeste do Brasil. Rev Bras Geocienc, Vol. 24 (4): 223-232. 
625 ASSINE ML. 2007. Bacia do Araripe. B Geoci Petrobras, Vol. 15 (2):371-389

626 AZEVEDO RPF, VASCONCELLOS PL, CANEDIRO CRA, BERGQVIST LP. 2007. Restos 627 microscópicos de vertebrados fósseis do Grupo Bauru (Neocretáceo), no oeste do Estado de 628 São Paulo, Brasil. In: CARVALHO IS, CASSAB RCT, SCHWANKE C, CARVALHO 629 MA, FERNANDES ACS, RODRIGUES MAC, CARVALHO MSS, ARAI M, OLIVEIRA MEQ. 2007. Paleontologia: Cenários de Vida. Rio de Janeiro: Interciência, Vol. 1, pp. 541549.

BÁEZ AM, MOURA GJ, GÓMEZ RO. 2009. Anurans from the Lower Cretaceous Crato Formation of northeastern Brazil: implications for the early divergence of neobatrachians. Cretaceous Res, Vol. 30 (4):829-846.

BARLING N, MARTILL DM, HEADS SW, GALLIEN F. 2015. High fidelity preservation of fossil insects from the Crato Formation (Lower Cretaceous) of Brazil. Cretaceous Res, Vol. 52 (B):605-622.

BARDEN HE, BERGMANN U, EDWARDS NP, EGERTON VM, MANNING PL, PERRY S, VAN VEELEN A, WOGELIUS RA, VAN DONGEN BE. 2014. Bacteria or melanosomes? A geochemical analysis of micro-bodies on a tadpole from the Oligocene Enspel Formation of Germany. Palaeobiodivers Palaeoenviron, pp. 1-13.

BARRETT PM, EVANS DC, CAMPIONE NE. 2015. Evolution of dinosaur epidermal structures. Biol Lett, Vol. 11 (6):20150229.

BARTHEL KW, SWINBURNE NHM, MORRIS SC (eds). 1994. Solnhofen: A Study in Mesozoic Palaeontology. Cambridge: Cambridge University Press, 246 p.

BEHRENSMEYER AK. 1978. Taphonomic and Ecologic Information from Bone Weathering. Paleobiology, Vol. 4 (2): 150-162.

BEHRENSMEYER AK. 1982. Time resolution in fluvial vertebrate assemblages. Paleobiology, Vol. 8 (3): 211-227.

BEHRENSMEYER AK. 1988. Vertebrate preservation in fluvial channels. Palaeogeogr palaeocl, Vol. 63 (1): 183-199.

BENTON MJ, FORTH J, LANGER MC. 2014. Models for the rise of the dinosaurs. Curr Biol, Vol. 24 (2), R87-R95.

BOSTWICK K, PRUM RO. 2005. Courting bird sings with stridulating wing feathers. Science, Vol. 309 (5735): 736. 
656 BRIGGS DEG. 2003. The role of decay and mineralization in the preservation of soft-bodied

657

658

659

660

661

662

663

664

665

666

667

668

669

670

671

672

673

674

675

676

677

678

679

680

681

682

683

684

685

686 fossils. Annu Rev Earth Planet Sci, Vol. 31 (1):275-301.

BUTLER RJ, BARRETT PM. 2008. Palaeoenvironmental controls on the distribution of Cretaceous herbivorous dinosaurs. Naturwissenschaften, Vol. 95 (11):1027-1032.

CANDEIRO CRA, AGNOLIN F, MARTINELLI AG, BUCKUP PA. 2012a. First bird remains from the Upper Cretaceous of the Peirópolis site, Minas Gerais state, Brazil. Geodiversitas, Vol. 34 (3):617-624.

CANDEIRO CRA, CAU A, FANTI F, NAVA WR, NOVAS FE. 2012b. First evidence of an unenlagiid (Dinosauria, Therapoda, Maniraptora) from the Bauru Group, Brazil. Cretaceous Res, Vol. 37 pp. 223-226.

CARNEY RM, VINTHER J, SHAWKEY MD, D'ALBA L, ACKERMAN J. 2012. New evidence on the colour and nature of the isolated Archaeopteryx feather. Nature Communications, Vol. 3, pp. 1-6.

CARVALHO IS. 1995. As pistas de dinossauros da Ponta da Guia (Bacia de São Luís, Cretáceo Superior-Maranhão, Brasil). An Acad Bras Ciênc, Vol. 67 (4):413-432.

CARVALHO IS, GONÇALVES RA. 1994. Pegadas de dinossauros Neocretácicas da Formação Itapecuru, Bacia de São Luís (Maranhão, Brasil). An Acad Bras Ciênc, Vol. 66 (3):279-292.

CARVALHO IS, ARAÚJO SAF. 1995. A distribuição geográfica dos fósseis e icnofósseis de Dinosauria na Bacia de São Luís. Anais da 47a Reunião Anual da Sociedade Brasileira para o Progresso da Ciência, São Luís: SBPC, Vol. 2, pp. 439.

CARVALHO IS, PEDRÃO E. 1998. Brazilian theropods from the equatorial Atlantic margin: behavior and environmental setting, aspects of Theropod Paleobiology. Gaia, Vol. 15, pp. 369-378.

CARVALHO IS, VIANA MSS, FILHO MFDL. 1995. Os icnofósseis de dinossauros da bacia do Araripe (Cretáceo Inferior, Ceará-Brasil). An Acad Bras Ciênc, Vol. 67 (4):433-442.

CARVALHO IS, NOVAS FE, AGNOLÍN FL, ISASI MP, FREITAS FI, ANDRADE JA. $2015 a$. A Mesozoic bird from Gondwana preserving feathers. Nature Commun, Vol. 6, pp. 1-5.

CARVALHO IS, NOVAS FE, AGNOLÍN FL, ISASI MP, FREITAS FI, ANDRADE JA. $2015 b$. A new genus and species of enantiornithine bird from the Early Cretaceous of Brazil. Braz J Geol, Vol. 45 (2):161-171.

CARVALHO MS, SANTOS MECM. 2005. Histórico das pesquisas paleontológicas na Bacia do 
687

688

689

690

691

692

693

694

695

696

697

698

699

700

701

702

703

704

705

706

707

708

709

710

711

712

713

714

715

716 717

Araripe, Nordeste do Brasil. Anuário do Instituto de Geociências - UFRJ, Vol. 28 (1):1534.

CHEN PJ, DONG ZM, ZHEN SN. 1998. An exceptionally well-preserved theropod dinosaur from the Yixian Formation of China. Nature, Vol. 391 (6663):147-152.

CHRISTIANSEN NA, TSCHOPP E. 2010. Exceptional stegosaur integument impressions from the Upper Jurassic Morrison Formation of Wyoming. Swiss J Geosci, Vol. 103 (2):163-171.

CLARKE JA, KSEPKA DT, SALAS-GISMONDI R, ALTAMIRANO AJ, SHAWKEY MD, D'ALBA L, VINTHER J, DEVRIES TJ, BABY P. 2010. Fossil evidence for evolution of the shape and color of penguin feathers. Science, Vol. 330 (6006):954-957.

CLARKE JA. 2013. Feathers before flight. Science, Vol. 340 (6133):690-692

CLARK CJ, ELIAS DO, PRUM RO. 2011. Aeroelastic flutter produces hummingbird feather songs. Science, Vol. 333 (6048):1430-1433.

COIMBRA JC, ARAI M, CARREÑO AL. 2002. Biostratigraphy of Lower Cretaceous microfossils from the Araripe basin, northeastern Brazil. Geobios, Vol. 35 (6):687-698.

CORIA RA, CHIAPPE LM. 2007. Embryonic skin from Late Cretaceous sauropods (Dinosauria) of Auca Mahuevo, Patagonia, Argentina. J Paleontol, Vol. 81 (6):1528-1532.

CZERKAS SA. 1992. Discovery of dermal spines reveals a new look for sauropod dinosaurs. Geology, Vol. 20 (12):1068-1070.

DAVENPORT LJ. 1979. Shag swallowed by monkfish. Br Birds, Vol. 72, pp. 77-78.

DAVIS M. 2012. Census of dinosaur skin reveals lithology may not be the most important factor in increased preservation of hadrosaurid skin. Acta Palaeontol Pol, Vol. 59 (3):601-605.

DAVIS PG, BRIGGS DEG. 1995. Fossilization of feathers. Geology, Vol. 23 (9):783-786.

DELCOURT R, GRILLO ON. 2015. On maniraptoran material (Dinosauria: Theropoda) from the Vale do Rio do Peixe Formation, Bauru Group, Brazil. Rev Bras Paleontolog, Vol. 17 (3):307-316.

D'EMIC MD. 2015. Response to Comments on "Evidence for mesothermy in dinosaurs". Science, Vol. 348 (6238):982.

DIAL KP. 2003. Wing-assisted incline running and the evolution of flight. Science, Vol. 299 (5605):402-404.

DIAL KP, JACKSON BE, SEGRE P. 2008. A fundamental avian wing-stroke provides a new perspective on the evolution of flight. Nature, Vol. 451 (7181):985-989. 
718 DIETZE K. 2007. Redescription of Dastilbe crandalli (Chanidae, Euteleostei) from the Early

719

720

721

722

723

724

725

726

727

728

729

730

731

732

733

734

735

736

737

738

739

740

741

742

743

744

745

746

747

748

Cretaceous Crato Formation of north-eastern Brazil. J Vertebr Paleontology, Vol. 27 (1):816.

DIMOND CC, CABIN RJ, BROOKS JS. 2011. Feathers, dinosaurs, and behavioral cues: defining the visual display hypothesis for the adaptative function of feathers in non-avian theropods. Bios, Vol. 82 (3):58-63.

DODSON P, BEHRENSMEYER AK, BAKKER RT, MCINTOSH JS. 1980. Taphonomy and paleoecology of the dinosaur beds of the Jurassic Morrison Formation. Paleobiology, Vol. 6 (2): 208-232.

DUMBACHER JP, WAKO A, DERRICKSON SR, SAMUELSON A, SPANDE TF, DALY JW. 2004. Melyrid beetles (Choresine): A putative source for the batrachotoxin alkaloids found in poison-dart frogs and toxic passerine birds. Proc Nat Acad Sci U.S.A., Vol. 101 (45):15857-15860.

DUNCAN RM, JENSEN WI. 1976. A relationship between avian carcasses and living invertebrates in the epizootiology of avian botulism. $J$ Wildl Dis, Vol. 12 (1):116-126.

EGERTON V, WOGELIUS R, NORELL M, EDWARDS N, SELLERS W, BERGMANN U, SOKARAS D, ALONSO-MORI R, IGNATYEV K, van VEELEN A, ANNÉ J, van DONGEN B, KNOLL F, MANNING P. 2015. The mapping and differentiation of biological and environmental elemental signatures in the fossil remains of a 50 million year old bird. J Anal At Spectrom, 8 p.

ELIAS FA, BERTINI RJ, MEDEIROS MAA. 2007. Velociraptorinae (Maniraptoriformes) teeth from the Coringa Flagstone outcrop, Middle Cretaceous of the São Luís-Grajaú Basin, Maranhão State, northern-northeastern Brazil. In: CARVALHO IS, CASSAB RCT, SCHWANKE C, CARVALHO MA, FERNANDES ACS, RODRIGUES MAC, CARVALHO MSS, ARAI M, OLIVEIRA MEQ. 2007. Paleontologia: Cenários de Vida. Rio de Janeiro: Interciência, Vol. 1, pp. 315-325.

FEDUCCIA A. 1993. Aerodynamic model for the early evolution of feathers provided by Propithecus (Primates, Lemuridae). J Theor Biology, Vol. 160 (2):159-164.

FIELD DJ, D'ALBA L, VINTHER J, WEBB SM, GEARTY W, SHAWKEY MD. 2013. Melanin concentration gradients in modern and fossil feathers. PloS One, Vol. 8 (3):e59451. FIELDING S, MARTILL DM, NAISH D. 2005. Solnhofen-style soft-tissue preservation in a 
749

750

751

752

753

754

755

756

757

758

759

760

761

762

763

764

765

766

767

768

769

770

771

772

773

774

775

776

777

778

779

new species of turtle from the Crato Formation (Early Cretaceous, Aptian) of north-east Brazil. Palaeontology, Vol. 48 (6):1301-1310.

FIGUEIREDO RG, KELLNER AWA. 2009. A new crocodylomorph specimen from the Araripe Basin (Crato Member, Santana Formation), northeastern Brazil. Paläont Z, Vol. 83 (2):323331.

FOTH C. 2012. On the identification of feather structures in stem-line representatives of birds: evidences from fossils and actuopalaeontology. Paläont Z, Vol. 86 (1):92-102.

FOTH C, TISCHLINGER H, RAUHUT OW. 2014. New specimen of Archaeopteryx provides insights into the evolution of pennaceous feathers. Nature, Vol. 511 (7507):79-82.

FRENCH TW. 1981. Fish attack on black guillemot Cepphus grylle and common eider Somateria mollissima in Maine USA. Wilson Libr Bull, Vol. 93, pp. 279-280.

FUCHENG Z, ZHOU Z, DYKE G. 2006. Feathers and 'feather-like' integumentary structures in Liaoning birds and dinosaurs. Geol J, Vol. 41 (3-4):395-404.

GAUTHIER J. 1986. Saurischian monophyly and the origin of birds. Memoirs of the California Academy of Sciences, Vol. 8, pp. 1-55.

GLUCKMAN TL, CARDOSO, GC. 2010. The dual function of barred plumage in birds: camouflage and communication. J Evolution Biol, Vol. 23 (11): 2501-2506.

GODEFROIT P, CAU A, DONG-YU H, ESCUILLIÉ F, WENHAO W, DYKE G. 2013. A Jurassic avialan dinosaur from China resolves the early phylogenetic history of birds. Nature, Vol. 498 (7454):359-362.

GODEFROIT P, SINITSA SM, DHOUAILLY D, BOLOTSKY YL, SIZOV AV, MCNAMARA ME, BENTON, MJ, SPAGNA P. 2014. A Jurassic ornithischian dinosaur from Siberia with both feathers and scales. Science, Vol. 345 (6195):451-455.

GÖHLICH UB, CHIAPPE LM. 2006. A new carnivorous dinosaur from the Late Jurassic Solnhofen archipelago. Nature, Vol. 440 (7082): 329-332.

GRADY JM, ENQUIST BJ, DETTWEILER-ROBINSON E, WRIGHT NA, SMITH FA. 2014. Evidence for mesothermy in dinosaurs. Science, Vol. 344 (6189):1268-1272.

GRADY JM, ENQUIST BJ, DETTWEILER-ROBINSON E, WRIGHT NA, SMITH FA. 2015. Response to Comments on "Evidence for mesothermy in dinosaurs". Science, Vol. 348 (6238):982.

GRIMALDI D, ENGEL MS. 2005. Evolution of the Insects. Cambridge University Press, 772 p. 
780

781

782

783

784

785

786

787

788

789

790

791

792

793

794

795

796

797

798

799

800

801

802

803

804

805

806

807

808

809

810

HAN G, CHIAPPE LM, JI SA, HABIB M, TURNER AH, CHINSAMY A, LIU X, HAN L. 2014. A new raptorial dinosaur with exceptionally long feathering provides insights into dromaeosaurid flight performance. Nature Comm, Vol. 5, pp. 1-9.

HEERS AM, DIAL KP. 2012. From extant to extinct: locomotor ontogeny and the evolution of avian flight. Trends Ecol Evol, Vol. 27 (5):296-305.

HEIMHOFER U, ARIZTEGUI D, LINNIGER M, HESSELBO SP, MARTILL DM, NETTO, AMR. 2010. Deciphering the depositional environment of the laminated Crato fossil beds (Early Cretaceous, Araripe Basin, North-eastern Brazil). Sedimentology, Vol. 52 (2):677694.

HOLTZ TR. 1996. Phylogenetic taxonomy of the Coelurosauria (Dinosauria: Theropoda). $J$ Paleont, Vol. 70 (3):536-538.

HOLZ M, SIMÕES MG. 2002. Elementos fundamentais de tafonomia. Porto Alegre: Editora Universidade/UFRGS. 231 p.

HUENE F. von. 1914. Beiträge zur Geschichte der Archosaurier. Geologische und Paläontologische Abhandlungen. Neue Folge, Vol. 13, pp. 1-53.

IRESTEDT M, JØNSSON KA, FJELDSÅ J, CHRISTIDIS L, ERICSON PGP. 2009. An unexpectedly long history of sexual selection in birds-of-paradise. BMC Evol Biol, Vol. 9 (1):235-246.

JI Q, JI SA. 1996. On the discovery of the earliest fossil bird in China (Sinosauropteryx gen. nov.) and the origin of birds. Chinese Geology, Vol. 233 (3):1-4.

JI SA, JI Q, LÜ J, YUAN C. 2007. A new Giant compsognathid dinosaur with long filamentous integuments from Lower Cretaceous of northeastern China. Acta Geol Sinica-Engl, Vol. 81 (1):8-15.

KELLNER AWA. 1996a. Fossilized theropod soft tissue. Nature, Vol. 379, pp. 32.

KELLNER AWA. 1996b. Reinterpretation of a remarkably well preserved pterosaur soft tissue from the Early Cretaceous of Brazil. J Vertebr Paleontology, Vol. 16 (4):718-722.

KELLNER AWA. 1999. Short Note on a new dinosaur (Theropoda, Coelurosauria) from the Santana Formation (Romualdo Member, Albian), northeastern Brazil. Bol Mus Nac NS, Geol, Vol. 49, pp. 1-8.

KELLNER AWA. 2002. A review of avian Mesozoic fossil feathers. In: CHIAPPE LM, WITMER LM. 2002. Mesozoic birds above the heads of dinosaurs. California: University of 
811 California Press. pp. 389-404.

812 KELLNER AWA, MAISEY J, CAMPOS DA. 1994. Fossil down feather from the Lower 813 Cretaceous of Brazil. Palaeontology, Vol. 37 (3):489-492.

814 KELLNER AWA, CAMPOS DA. 1996. First Early Cretaceous dinosaur from Brazil with 815 comments on Spinosauridae. Neues Jahrb Geol P-A, Vol. 199 (2):151-166.

816 KOSCHOWITZ MC, FISCHER C, SANDER M. 2014. Beyond the rainbow. Science, Vol. 346 $817 \quad(6208): 416-418$.

818 LANGER MC, NESBITT SJ, BITTENCOURT JS, IRMIS RB. 2013. Non-dinosaurian 819 dinosauromorpha. In: NESBITT SJ, DESOJO JB, IRMIS RB (eds). 2013. Anatomy, 820 phylogeny and palaeobiology of early archosaurs and their kin. London: Geol Soc SP, Vol. $821 \quad 379,31 \mathrm{p}$.

822 LAYBOURNE RC, DEEDRICK DW, HUEBER FM. 1994. Feather in Amber is Earliest new 823 world fossil of Picidae. Wilson Bull, Vol. 106 (1):18-25.

824 LEITE KJG, HESSEL MH. 2011. Novas evidências de pequenos dinossauros no Membro Crato 825 da Formação Santana, Aptiano da Bacia do Araripe, Brasil. Fortaleza-CE: Anais do XI 826 Encontro de Pós-Graduação e Pesquisa da UNIFOR. Universidade de Fortaleza, 5 p. ISSN: $827 \quad 1808-8457$.

828 LI Q, GAO KQ, VINTHER J, SHAWKEY M, CLARKE JA, D'ALBA L, MENG Q, BRIGGS 829 DEG, PRUM RO. 2010. Plumage color patterns of an extinct dinosaur. Science, Vol. 327 830 (5971):1369-1372.

831 LI Q, GAO KQ, MENG Q, CLARKE JA, SHAWKEY M, D'ALBA L, PEI P, ELLISON M, 832 NORELL MA, VINTHER J. 2012. Reconstruction of Microraptor and the evolution of 833 iridescent plumage. Science, Vol. 335 (6073):1215-1219.

834 LI Q, CLARKE JA, GAO KQ, ZHOU CF, MENG Q, LI D, D’ALBA L, SHAWKEY MD 2014. 835 Melanosome evolution indicates a key physiological shift within feathered dinosaurs Nature, $836 \quad$ Vol. $507(7492): 350-353$.

837 LIMA RJC, SARAIVA AAF, LANDREDI S, NOBRE MAL, FREIRE PTC, SASAKI JM. 2007. 838 Caracterização espectroscópica de peixe do Período Cretáceo (Bacia do Araripe). Quim $839 \quad$ Nova, Vol. 30 (1):22-24.

840 LINDGREN J, UVDAL P, SJÖVALL P, NILSSON DE, ENGDAHL A, SCHULTZ BP, THIEL 841 V. 2012. Molecular preservation of the pigment melanin in fossil melanosomes. Nature 
842

843

844

845

846

847

848

849

850

851

852

853

854

855

856

857

858

859

860

861

862

863

864

865

866

867

868

869

870

871

872

Comm, Vol. 3. pp. 824-831.

LINDGREN J, SJÖVALL P, CARNEY RM, UVDAL P, GREN JA, DYKE G, SCHULTZ BP, SHAWKEY MD, BARNES KR, POLCYN MJ. 2014. Skin pigmentation provides evidence of convergent melanism in extinct marine reptiles. Nature, Vol. 506 (7489):484-488.

LINDGREN J, SJÖVALL P, CARNEY RM, CINCOTTA A, UVDAL P, HUTCHESON SW, GUSTAFSSON O, LEFÈVRE U, ESCUILLIÉ F, HEIMDAL J, ENGDAHL A, GREN JA, KEAR BP, WAKAMATSU K, YANS J, Godefroit P. 2015a. Molecular composition and ultrastructure of Jurassic paravian feathers. Sci Rep-UK, Vol. 5, pp. 1-13.

LINDGREN J, MOYER A, SCHWEITZER MH, SJÖVALL P, UVDAL P, NILSSON DE, HEIMDAL J, ENGDAHL A, GREN JA, SCHULTZ BP, KEAR BP. 2015b. Interpreting melanin-based coloration through deep time: a critical review. Proc $R$ Soc B, Vol. 282 (1813):20150614.

LUCAS AM, STETTENHEIM PR. 1972. Avian Anatomy: Integument (part 1 and 2). Agriculture Handbook, Vol. 362. 750 p.

MACHADO EB, KELLNER AWA. 2007. On a supposed ornithischian dinosaur from the Santana Formation, Araripe Basin, Brazil. In: CARVALHO IS, CASSAB RCT, SCHWANKE C, CARVALHO MA, FERNANDES ACS, RODRIGUES MAC, CARVALHO MSS, ARAI M, OLIVEIRA MEQ. 2007. Paleontologia: Cenários de Vida. Rio de Janeiro: Interciência, Vol. 1, pp. 291-299.

MACHADO EB, CAMPOS DA, KELLNER AWA. 2008. On a theropod scapula (Upper Cretaceous) from the Marília Formation, Bauru Group, Brazil. Paläont Z, Vol. 82 (3):308313.

MAISEY JG. 1991. Santana fossils: an illustrated atlas. Neptune City, New Jersey: Tfh Publications Inc., 469 p.

MANSILLA HG, WOLFGANG S, VARELA N, LEPPE M. 2013. Eocene fossil feather from King George Island, South Shetland Islands, Antarctica. Antarct Sci, pp. 1-5.

MAYR G, PETERS DS, PLODOWSKI G, VOGEL O. 2002. Bristle-like integumentary structures at the tail of the horned dinosaur Psittacosaurus. Naturwissenschaften, Vol. 89 (8):361-365.

MARSH OC. 1881. Principal characters of American Jurassic dinosaurs, Part V. Am J Sci, Vol. 21 (125):417-423. 
873 MARSOLA JCA, TINNER GG, MONTEFELTRO FC, SAYÃO JM, HSIOU AS, LANGER

874

875

876

877

878

879

880

881

882

883

884

885

886

887

888

889

890

891

892

893

894

895

896

897

898

899

900

901

902

903

MC. 2014. The first fossil avian egg from Brazil. Alcheringa, Vol. 38, pp. 1-5.

MARTILL DM. 1988. Preservation of fish in the Cretaceous Santana Formation of Brazil. Palaeontology, Vol. 31 (1): 1-18.

MARTILL DM. 1989. The Medusa Effect. Geology Today, Vol. 5 (6):201-205.

MARTILL, D.M. 1990. Macromolecular resolution of fossilized muscle tissue from an elopomorph fish. Nature, Vol. 346, pp. 171-172.

MARTILL DM. 1993. Fossils of the Santana and Crato Formations, Brazil. Field Guide to Fossils no. 5. London: The Palaeontological Association, 159 p.

MARTILL DM. 1997. Fish oblique to bedding in early diagenetic concretions from the Cretaceous Santana Formation of Brazil, implications for substrate consistency. Paleontology, Vol. 40 (4):1011-1026.

MARTILL DM, UNWIN DM. 1989. Exceptionally well preserved pterosaur wing membrane from the Cretaceous of Brazil. Nature, Vol. 340, pp. 138 - 140.

MARTILL DM, FILGUEIRA JBM. 1994. A new feather from the Lower Cretaceous of Brazil. Palaeontology, Vol. 37 (3):483-488.

MARTILL DM, FREY E. 1995. Colour patterning preserved in Lower Cretaceous birds and insects: The Crato Formation of N. E. Brazil. Neues Jahrb Geol P-M, Vol. 2. pp. 118-128.

MARTILL DM, DAVIS PG. 2001. A feather with possible ectoparasite eggs from the Crato Formation (Lower Cretaceous, Aptian) of Brazil. Neues Jahrb Geol P-A, Vol. 219 (3):241259.

MARTILL DM, CRUICKSHANK ARI, FREY E, SMALL PG, CLARKE M. 1996. A new crested maniraptoran dinosaur from the Santana Formation (Lower Cretaceous) of Brazil. $J$ Geol Soc London, Vol. 153 (1):5-8.

MARTILL DM, BECHLY G, LOVERIDGE RF. (eds). 2007a. The Crato fossil beds of Brazil: A window into an ancient world. Cambridge: Cambridge University Press, 674 p.

MARTILL DM, LOVERIDGE RF, HEIMHOFER U. 2007b. Halite pseudomorphs in the Crato Formation (Early Cretaceous, Late Aptian-Early Albian), Araripe Basin, northeast Brazil: further evidence for hypersalinity. Cretaceous Res, Vol. 28 (4):613-620.

MARTILL DM, BRITO PM, WASHINGTON-EVANS J. 2008a. Mass mortality of fishes in the Santana Formation (Lower Cretaceous,? Albian) of northeast Brazil. Cretaceous Res, Vol. 
904

905

906

907

908

909

910

911

912

913

914

915

916

917

918

919

920

921

922

923

924

925

926

927

928

929

930

931

932

933

934

29 (4):649-658.

MARTILL DM, LOVERIDGE LR, HEIMHOFER U. 2008b. Dolomite pipes in the Crato Formation fossil Lagerstätte (Lower Cretaceous, Aptian), of northeastern Brazil. Cretaceous Res, Vol. 29 (1):78-86.

MARTILL DM, LOVERIDGE LR, MOHR BAR, SIMMONDS E. 2012. A wildfire origin for terrestrial organic debris in the Cretaceous Santana Formation fossil Lagerstätte (Araripe Basin) of north-east Brazil. Cretaceous Res, Vol. 34, pp. 135-141.

MARTIN LD. 1998. The big flap. Sciences, Vol. 38 (2):39-44.

MARTINS-NETO RG, KELLNER AWA. 1988. Primeiro registro de pena na Formação Santana (Cretáceo Inferior), Bacia do Araripe, Nordeste do Brasil. An Acad Bras Ciênc, Vol. 60 (1):61-68.

MCNAMARA ME. 2013. The taphonomy of colour in fossil insects and feathers. Palaeontology, Vol. 53 (3):557-575.

MCKELLAR RC, CHATTERTON BDE, WOLFE AP, CURRIE PJ. 2011. A diverse assemblage of Late Cretaceous dinosaur and bird feathers from Canadian amber. Science, Vol. 333 (6049):1619-1622

MOHR BA, BERNARDES-DE-OLIVEIRA ME, LOVERIDGE R, PONS D, SUCERQUIA PA, CASTRO-FERNANDES MC. 2015. Ruffordia goeppertii (Schizaeales, Anemiaceae) - A common fern from the Lower Cretaceous Crato Formation of northeast Brazil. Cretaceous Res, Vol. 54, pp. 17-26.

MYHVOLD NP. 2015. Response to Comments on "Evidence for mesothermy in dinosaurs". Science, Vol. 348 (6238):982.

NAISH D, MARTILL DM, FREY E. 2004. Ecology, systematics and biogeographical relationships of Dinosaurs, including a new theropod, from the Santana Formation (?Albian, Early Cretaceous) of Brazil. Historical Biol, Vol. 16 (2-4):57-70

NESBITT SJ, BARRETT PM, WERNING S, SIDOR CA, CHARIG AJ. 2013. The oldest dinosaur? A Middle Triassic dinosauriform from Tanzania. Biol Lett, Vol. 9 (1):20120949.

NORELL MA. 2011. Fossilized feathers. Science, Vol. 333 (6049):1590-1591.

NOVAS FE, RIBEIRO LCB, CARVALHO IS. 2005. Maniraptoran theropod ungual from the Marília Formation (Upper Cretaceous), Brazil. Rev Mus Argent Cienc Nat, Vol. 7 (1):31-36.

O'BRIEN GC, JACOBS F, EVANS SW, SMIT NJ. 2014. First observation of African tigerfish 
935

936

937

938

939

940

941

942

943

944

945

946

947

948

949

950

951

952

953

954

955

956

957

958

959

960

961

962

963

964

965

Hydrocynus vittatus predating on barn swallows Hirundo rustica in flight. J Fish Biol, Vol. 84 (1):263-266.

OLIVEIRA GR, KELLNER AW. 2015. Juvenile specimens of Araripemys Price, 1973 (Pelomedusoides, Araripemydidae) from the Crato Formation, Araripe Basin (No. e1134). PeerJ PrePrints. pp. 1-2.

OLSON SL, ALVARENGA HMF. 2002. A new genus of small teratorn from the Middle Tertiary of the Taubaté Basin, Brazil (Aves: Terathornitidae). P Biol Soc Wash, Vol. 115 (4):701-705.

PERSONS WS, CURRIE PJ. 2015. Bristles before down: A new perspective on the functional origin of feathers. Evolution, Vol. 69 (4):857-862.

PERRICHOT V, MARION L, NÉRAUDAU D, VULLO R, TAFFOREAU P. 2008. The early evolution of feathers: fossil evidence from Cretaceous amber of France. P Roy Soc B, Vol. 275 (1639):1197-1202.

PERRY MC, OLSEN GH, RICHARDS RA, OSENTON PC. 2013. Predation on Dovekies by Goosefish Over Deep Water in the Northwest Atlantic Ocean. Northeast Nat, Vol. 20 (1):148-154.

PINHEIRO FL, HORN BL, SCHULTZ CL, ANDRADE JA, SUVERQUIA PA. 2012. Fossilized bacteria in a Cretaceous pterosaur headcrest. Lethaia, Vol. 45 (4):495-499.

PROCTOR NS, LYNCH PJ. 1993. Manual of ornithology: avian structure and function. Yale University Press, $340 \mathrm{p}$.

PRUM RO, BRUSH AH. 2002. The evolutionary origin and diversification of feathers. $Q$ Rev Biol, Vol. 77 (3):261-295.

QIANG J, CURRIE PJ, NORELL MA, SHU-AN J. 1998. Two feathered dinosaurs from northeastern China. Nature, Vol. 393 (6687):753-761.

RAUHUT OWM, FOTH C, TISHLINGER H, NORELL MA. 2012. Exceptionally preserved juvenile megalosauroid theropod dinosaur with filamentous integument from the Late Jurassic of Germany. Proc Nat Acad Sci U.S.A., Vol. 109 (29):11746-11751.

RAUTIAN AS. 1978. A unique bird feather from Jurassic lake deposits in the Karatau. Paleontol $J$, Vol. 1978 (4):520-528.

RUBEN JA, JONES TD. 2000. Selective factors associated with the origin of fur and feathers. Am Zool, Vol. 40 (4):585-596. 
966 SANTOS RS. 1950. Vestígio de ave fóssil nos folhelhos betuminosos de Tremembé, S. Paulo. 967 An Acad Bras Cienc, Vol. 23 (4)7-8.

968 SANZ JL, BONAPARTE JF, LACASA A. 1988. Unusual Early Cretaceous birds from Spain. 969 Nature, Vol. 331, pp. 433-435.

970 SANZ JL, CHIAPPE LM, PÉREZ-MORENO BP, BUSCAIONI AD, MORATALLA JJ, 971 ORTEGA F, POYATO-ARIZA FJ. 1996. An Early Cretaceous bird from Spain and its 972 implications for the evolution of avian flight. Nature, Vol. 382, pp. 442-445.

973 SAYÃO JM, UEJIMA AMK. 2009. Novos registros de penas isoladas na Formação Crato, 974 Grupo Santana, Bacia do Araripe, Nordeste do Brasil. In: REUNIÃO ANUAL REGIONAL 975 976 DA SOCIEDADE BRASILEIRA DE PALEONTOLOGIA. 2009. Sociedade Brasileira de Paleontologia, Crato-CE. Resumo. pp. 22.

SAYÃO JM, SARAIVA AAF, UEJIMA AMK. 2011. New evidence of feathers in the Crato Formation supporting a reappraisal on the presence of Aves. An Acad Bras Ciênc, Vol. 83 (1):197-210.

SAVELIEV SV, ALIFANOV VR. 2014. A new type of skin derivatives in ornithischian dinosaurs from the Late Jurassic of Transbaikalia (Russia). Dokl Biol Sci, Vol. 456 (1):182-

983 184.

SCHMITZ L, MOTANI R. 2011. Nocturnality in dinosaurs inferred from scleral ring and orbit 984 morphology. Science, Vol. 332 (6030):705-708.

SCHWEITZER MH, AVCI R, COLLIER T, GOODWIN MB. 2008. Microscopic, chemical and 987 molecular methods for examining fossil preservation. C R Palevol, Vol. 7 (2-3):159-184.

SEELEY HG. 1888. Classification of the Dinosauria. Geological Magazine (Decade III), Vol. 5 988 (01):45-46.

SHUFELDT RW. 1916. A fossil feather of Taubaté. Auk Vol. 33 pp. 206-207.

SICK H. 1984. Ornitologia brasileira, uma introdução. Vol. I. Brasília: Editora Universidade de 991 Brasília, 481 p.

992

SILVA AJP, LOPES RC, VASCONCELOS AM, BAHIA RBC. 2003. Bacias sedimentares 993 Paleozóicas e Meso-Cenozóicas Interiores. In: BIZZI LA, SCHOBBENHAUS C, VIDOTTI 994 995 RM, GONÇALVES JH. (eds). 2003. Geologia, Tectônica e Recursos Minerais do Brasil: 996 texto mapas e SIG. Brasília: CPRM - Serviço Geológico do Brasil. pp. 55-85.

SIMÕES TR, CALDWELL MW, KELLNER AWA. 2014. A new Early Cretaceous lizard 
997

998

999

1000

1001

1002

1003

1004

1005

1006

1007

1008

1009

1010

1011

1012

1013

1014

1015

1016

1017

1018

1019

1020

1021

1022

1023

1024

1025

1026

1027

species from Brazil, and the phylogenetic position of the oldest known South American squamates. J Syst Palaeontol, Vol. 13 (7):601-614.

SRIVASTAVA NK. 1996. Estromatolitos cretácicos continentais na Bacia do Araripe. An Acad Bras Ciênc, Vol. 68 (2):267.

STEVENS GC. 1989. The latitudinal gradient in geographical range: how so many species coexist in the tropics. Am Nat, Vol. 133 (2):240-256.

TALENT JA, DUNCAN PM, HANBY PL. 1966. Early Cretaceous feathers from Victoria. Emu, Vol. 64 (2):81-86.

TAVARES SAS, BRANCO FR, SANTUCCI RM. 2014. Theropod teeth from the Adamantina Formation (Bauru Group, Upper Cretaceous), Monte Alto, São Paulo, Brazil. Cretaceous Res, Vol. 50, pp. 59-71.

TEGELAAR EW, LEEUW JW, DERENNE S, LARGEAU C. 1989. A reappraisal of kerogen formation. Geochim Cosmichim Ac, Vol. 53 (11):3103-3106.

TILKENS MJ, WALL-SCHEFFLER C, WEAVER TD, STEUDEL-NUMBERS K. 2007. The effects of body proportions on thermoregulation: an experimental assessment of Allen's rule. J Hum Evol, Vol. 53 (3):286-291.

THOMAS DB, NASCIMBENE PC, DOVE CJ, GRIMALDI DA, JAMES HF. 2014. Seeking carotenoid pigments in amber-preserved fossil feathers. Sci Rep, Vol. 4, pp. 1-6.

TURNER AH, MAKOVICKY PJ, NORELL MA. 2007. Feather quill knobs in the dinosaur Velociraptor. Science, Vol. 317 (5845):1721-1721.

UNWIN DM. 1998. Feathers, filaments and theropod dinosaurs. Nature, Vol. 391 (6663):119120.

UNWIN DM, BAKHURINA NN. 1994. Sordes pilosus and the nature of the pterosaur flight apparatus. Nature, Vol. 371 (6492):62-64.

VALENTIN X, GOMEZ B, DAVIERO-GOMEZ V, CHARBONNIER S, FERCHAUD P, KIREJTSHUK AG, LICHT A, NÉRAUDEAU D, VULLO R, GARCIA G. 2014. Plantdominated assemblage and invertebrates from the lower Cenomanian of Jaunay-Clan, western France. CR Palevol, Vol. 13 (5):443-454.

VARRICCHIO DJ. 1995. Taphonomy of Jack's Birthday Site, a diverse dinosaur bonebed from the Upper Cretaceous Two Medicine Formation of Montana. Palaeogeogr, Palaeoclimatol, Paleoecol, Vol. 114 (2):297-323. 
1028 VARRICCHIO DJ, MARTIN AJ, KATSURA Y. 2007. First trace and body fossil evidence of a 1029 burrowing, denning dinosaur. P Roy Soc B, Vol. 274 (1616):1361-1368.

1030 VARRICCHIO DJ, SERENO PC, XIJIN Z, LIN T, WILSON JA, LYON GH. 2008. Mud1031 trapped herd captures evidence of distinctive dinosaur sociality. Acta Palaeontol Pol, Vol. $103253(4): 567-578$.

1033 VIANNA MSS, NEUMANN VHL. 2002. Membro Crato da Formação Santana, Chapada do 1034 Araripe, CE. Riquíssimo registro de fauna e flora do Cretáceo. In: SCHOBBENHAUS C, et 1035 al. (eds). Sítios Geológicos e Paleontológicos do Brasil. Departamento Nacional de Produção Mineral. Brasília-DF, 2002. pp. 113-120.

VINTHER J. 2015. A guide to the field of palaeo colour. BioEssays, Vol. 37 (6):1-14.

VINTHER J, BRIGGS DEG, PRUM RO, SARANATHAN V. 2008. The colour of fossil feathers. Biol Lett, Vol. 4 (5):522-525.

VINTHER J, BRIGGS DEG, CLARKE J, MAYR G, PRUM RO. 2010. Structural coloration in a fossil feather. Biol Lett, Vol. 6 (1):128-131.

VITEK N, VINTHER J, SCHIFFBAUER JD, BRIGGS DEG, PRUM RO. 2013. Exceptional three-dimensional preservation and colouration of an iridescent fossil feather from the Middle Eocene Messel Oil Shale. Paläont Z, Vol. 87 (4):493-503.

WAGNER JA. 1859. Über einige im lithographischen Schiefer neu aufgefundene Schildkröten und Saurier. Gelehrte Anzeigen der Bayerischen Akademie der Wissenschaften, Vol. 49, pp. 553.

WALDMAN M. 1970. A third specimen of a Lower Cretaceous feather from Victoria, Australia. Condor, Vol. 72 (3):377.

WETMORE A. 1943. The occurrence of feather impressions in the Miocene deposits of Maryland. Auk, Vol. 60 (3):440-441.

WILBY PR, MARTILL DM. 1992. Fossil fish stomachs: a microenvironment for exceptional preservation. Historical Biol, Vol. 6 (1): 25-36.

WILLIAMSON TE, KUES BS, WEISSMANN GS, STIDHAM TA, YURCHYK SL. 2009. A feather from the Upper Cretaceous (Lower Campanian) Point Lookout Sandstone, San Juan Basin, northwestern New Mexico. Cretaceous Res, Vol. 30 (3):547-550. 
1059

1060

1061

1062

1063

1064

1065

1066

1067

1068

1069

1070

1071

1072

1073

1074

1075

1076

1077

1078

1079

1080

1081

1082

1083

1084

1085

1086

1087

1088

1089

Trace metals as biomarkers for eumelanin pigment in the fossil record. Science, Vol. $\mathbf{3 3 3}$ (6049):1622-1626.

WOOD JM, THOMAS RG, VISSER J. 1988. Fluvial processes and vertebrate taphonomy: the upper cretaceous Judith River formation, south-central dinosaur Provincial Park, Alberta, Canada. Palaeogeogr palaeocl, Vol. 66 (1): 127-143.

WUTTKE M. 1983. Weichteil-Erhaltung'durch lithifizierte Mikroorganismen bei mittel-eozänen Vertebraten aus den Ölschiefern der 'Grube Messel'bei Darmstadt. Senck Leth, Vol. 64 (5/6):509-527.

XU X. 2006. Scales, feathers and dinosaurs. Nature, Vol. 440 (7082): 287-288.

XU X, GUO Y. 2009. The origin and early evolution of feathers insights from recent paleontological and neontological data. Vertebrat Palasiatic, Vol. 47 (4):311- 329.

XU X, ZHOU ZH, PRUM RO. 2001. Branched integumental structures in Sinornithosaurus and the origin of feathers. Nature, Vol. 410 (6825):200-204.XU X, ZHENG X, YOU H. 2009. A new feather type in a nonavian therapod and the early evolution of feathers. Proc Nat Acad Sci U.S.A. Vol. 106 (3):832-834.

XU X, ZHENG X, YOU H. 2010. Exceptional dinosaur fossils show ontogenetic development of early feathers. Nature, Vol. 464 (7293):1338-1341.

XU X, WANG K, ZHANG K, MA Q, XING L, SULLIVAN C, HU D, CHENG S, WANG S. 2012. A gigantic feathered dinosaur from the Lower Cretaceous of China. Nature, Vol. 484 (7392):92-95.

XU X, ZHOU Z, DUDLEY R, MACKEM S, CHUONG CM, ERICKSON GM, VARRICCHIO DJ. 2014. An integrative approach to understanding bird origins. Science, Vol. 346 (6215):1253293.

ZELENITSKY DK, THERRIEN F, ERICKSON GM, DEBUHR CL, KOBAYASHI Y, EBERTH DA, HADFIELD F. 2012. Feathered non-avian dinosaurs from North-America provide insight into wing origins. Science, Vol. 338 (6106):510-514

ZI J, YU X, LI Y, HU X, XU C, WANG X, LIU X, FU R. 2003. Coloration strategies in peacock feathers. Proc Nat Acad Sci U.S.A., Vol. 100 (22):12576-12578.

ZHANG F, KEARNS SL, ORR PL, BENTON MJ, ZHOU Z, JOHNSON D, XU X, WANG X. 2010. Fossilized melanosomes and the colour of Cretaceous dinosaurs and birds. Nature, Vol. 463 (7284):1075-1078. 
1090 ZHENG XT, YOU HL, XU X, DONG ZM. 2009. An Early Cretaceous heterodontosaurid 1091 dinosaur with filamentous integumentary structures. Nature, Vol. 458 (7236):333-336. 


\section{Table $\mathbf{1}$ (on next page) \\ Brazilian feather occurrences}

Table 1. The Brazilian fossil record of feathers formally described. 


\begin{tabular}{|c|c|c|c|c|c|}
\hline FEATHER & DEPOSIT & AGE & PRESERVATION & OBSERVATIONS & REFERENCE \\
\hline One primary remex & Tremembé Fm & $\begin{array}{l}\text { Paleogene } \\
\text { (Oligocene) }\end{array}$ & Carbonized & First record in the country & Shufeldt (1916 \\
\hline One contour feather & Tremembé Fm & $\begin{array}{l}\text { Paleogene } \\
\text { (Oligocene) }\end{array}$ & Carbonized & $\begin{array}{c}\text { Feather assigned to a Turdidae (Turdus } \\
\text { rufiventris) }\end{array}$ & Santos (1950) \\
\hline $\begin{array}{l}\text { Two pennaceous } \\
\text { feathers }\end{array}$ & Pirabas Fm & $\begin{array}{l}\text { Neogene } \\
\text { (Miocene) }\end{array}$ & Carbonized & Possible semiplumes or contour feathers & Ackerman $(196$ \\
\hline One primary remex & Santana Fm & $\begin{array}{c}\text { Cretaceous } \\
\text { (Aptian/Albian) }\end{array}$ & $\begin{array}{l}\text { Limonitc/ } \\
\text { Imprint }\end{array}$ & Asymmetrical feather attributed to birds & $\begin{array}{c}\text { Martins-Neto \& Ke } \\
\text { (1988) }\end{array}$ \\
\hline Contour feathers & Tremembé Fm & $\begin{array}{l}\text { Paleogene } \\
\text { (Oligocene) }\end{array}$ & $\begin{array}{l}\text { Carbonized/ } \\
\text { Imprint }\end{array}$ & $\begin{array}{c}\text { Several feathers associated with skeleton of } \\
\text { Taubacrex granivora }\end{array}$ & Alvarenga $(198$ \\
\hline Semiplume & Santana Fm & $\begin{array}{c}\text { Cretaceous } \\
\text { (Aptian/Albian) }\end{array}$ & Carbonized & Feather assigned to passerine birds & Martill \& Filgueira \\
\hline Down feather & Santana Fm & $\begin{array}{c}\text { Cretaceous } \\
\text { (Aptian/Albian) }\end{array}$ & Carbonized & $\begin{array}{l}\text { Feather assigned to thermoregulation function } \\
\text { of a bird }\end{array}$ & Kellner et al. (19 \\
\hline Contour feather & Santana Fm & $\begin{array}{c}\text { Cretaceous } \\
\text { (Aptian/Albian) }\end{array}$ & Melanosome preservation & Feather with (banded) color pattern preserved. & Martill \& Frey $(1 \mathrm{C}$ \\
\hline $\begin{array}{l}\text { One symmetrical } \\
\text { feather }\end{array}$ & Santana Fm & $\begin{array}{c}\text { Cretaceous } \\
\text { (Aptian/Albian) }\end{array}$ & Carbonized & $\begin{array}{l}\text { The biggest isolated feather associated with } \\
\text { ectoparasite eggs. Assigned to a bird. }\end{array}$ & $\begin{array}{l}\text { Martill \& Davis, }(1 \\
\text { 2001) }\end{array}$ \\
\hline $\begin{array}{l}\text { Plumulaceous } \\
\text { feathers }\end{array}$ & Santana Fm & $\begin{array}{c}\text { Cretaceous } \\
\text { (Aptian/Albian) }\end{array}$ & $\begin{array}{l}\text { No data. Presumably } \\
\text { carbonized }\end{array}$ & One plume and one semiplume & Sayão \& Uejima (2 \\
\hline $\begin{array}{l}\text { Plumulaceous } \\
\text { feathers }\end{array}$ & Santana Fm & $\begin{array}{c}\text { Cretaceous } \\
\text { (Aptian/Albian) }\end{array}$ & Carbonized & Eight contour feathers & Leite \& Hessel (2 \\
\hline Down feather & Santana Fm & $\begin{array}{c}\text { Cretaceous } \\
\text { (Aptian/Albian) }\end{array}$ & Carbonized & Feathers assigned to a bird & Sayão et al. (201 \\
\hline $\begin{array}{l}\text { Several rectrices, } \\
\text { remiges and } \\
\text { filamentous } \\
\text { feathers (possibly } \\
\text { contour feathers) }\end{array}$ & Santana Fm & $\begin{array}{c}\text { Cretaceous } \\
\text { (Aptian/Albian) }\end{array}$ & Carbonized & $\begin{array}{c}\text { Several feathers associated with a skeleton of } \\
\text { the enantiornithe Cratoavis cearensis. First } \\
\text { formally description of a Mesozoic bird in } \\
\text { Brazil. }\end{array}$ & Carvalho et al., 20 \\
\hline
\end{tabular}


Figure 1 (on next page)

Araripe Basin locality and lithology

Figure 1. The Araripe Basin locality, the stratigraphic columns, units and chronology. (Adapted and modified from Coimbra et al., 2002; Vianna \& Neumann, 2002; Assine, 2007) 

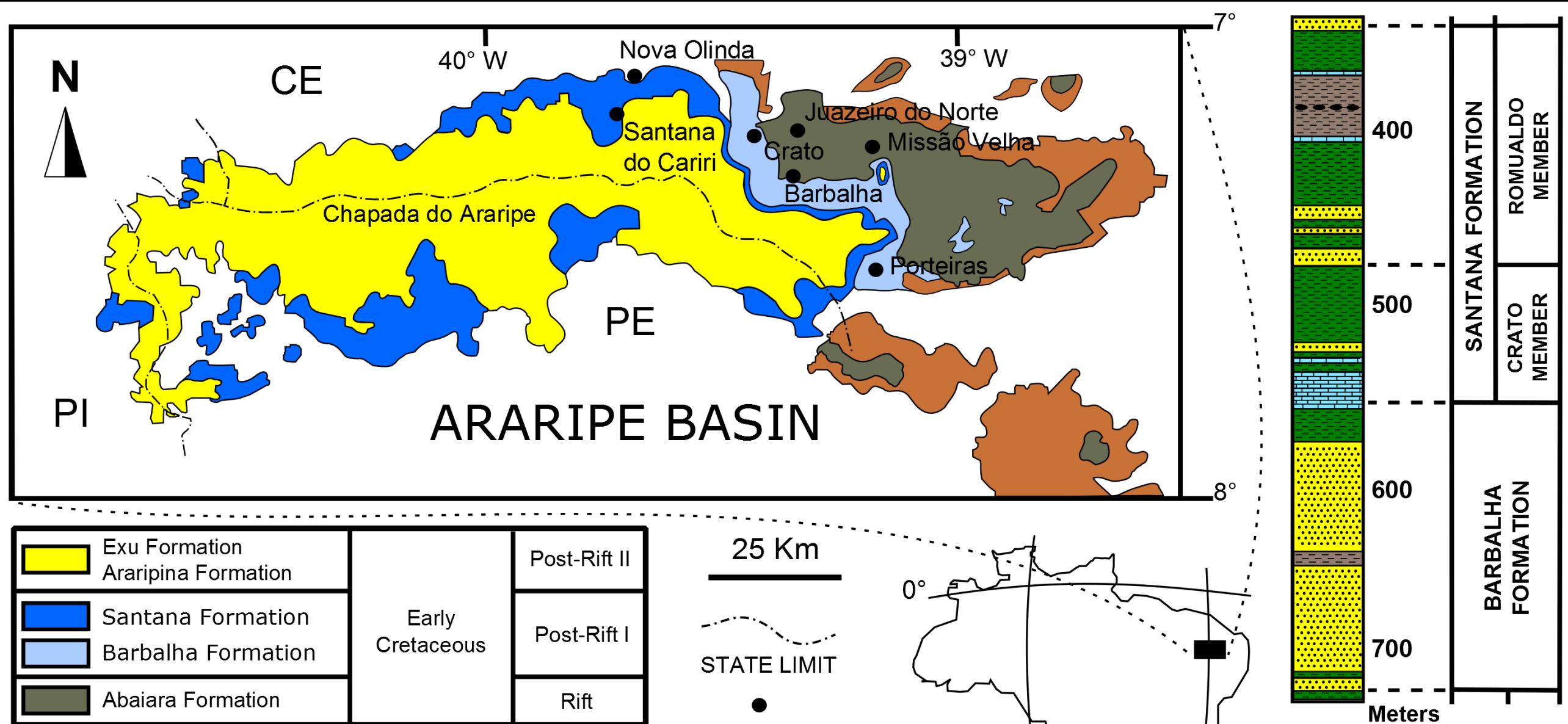

\begin{tabular}{|c|c|c|}
\hline $\begin{array}{l}\text { Exu Formation } \\
\text { Araripina Formation }\end{array}$ & \multirow{3}{*}{$\begin{array}{c}\text { Early } \\
\text { Cretaceous }\end{array}$} & Post-Rift II \\
\hline $\begin{array}{l}\text { Santana Formation } \\
\text { Barbalha Formation }\end{array}$ & & Post-Rift I \\
\hline Abaiara Formation & & Rift \\
\hline $\begin{array}{l}\text { Missão Velha Formation } \\
\text { Brejo Santo Formation }\end{array}$ & $\begin{array}{l}\text { Late } \\
\text { Jurassic }\end{array}$ & Pre-Rift \\
\hline Cariri Formation & Paleozoic & \\
\hline Basement & Precambrian & \\
\hline
\end{tabular}
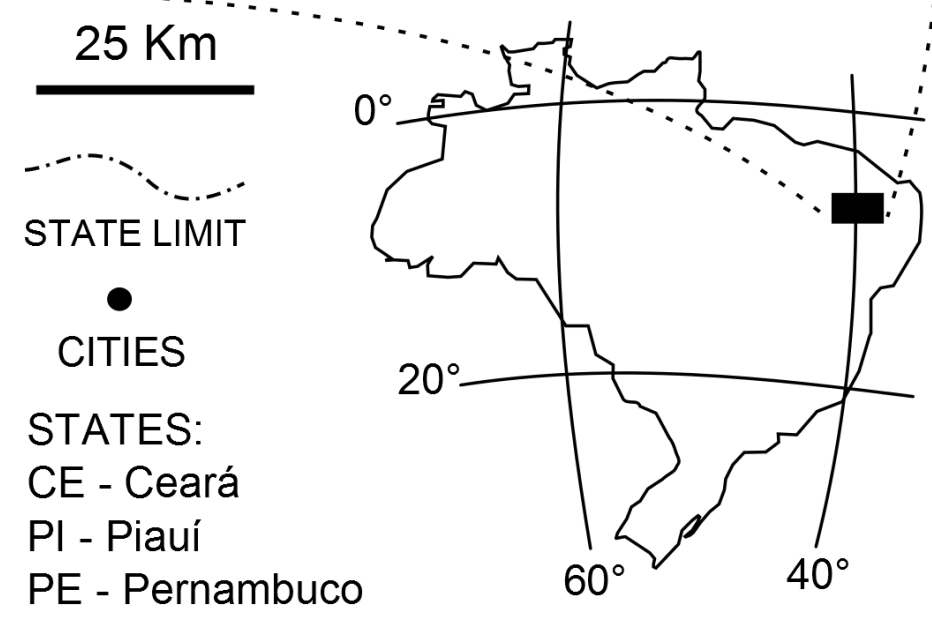

Meters

Limestone

Sandstone

Mudstone

Shale

Coquinas e concretions 


\section{Table 2 (on next page)}

Measures of the new specimens

Table 2. Values of the measures of the three specimens. Legend: NP - Not present.

Dimensions are in $\mathrm{mm}$ 
1

\begin{tabular}{cccccccc}
\hline Specimen & Width & Length & Larger barb & Minor barb & Calamus & Rachis & $\begin{array}{c}\text { Rachis } \\
\text { thickness }\end{array}$ \\
\hline GP/2E-7853 & 12,36 & 16,14 & 8,65 & 4,85 & NP & 9,43 & 0,49 \\
GP/2E-7854 & 12,76 & 19,00 & 17,83 & 4,30 & 0,24 & 12,03 \\
GP/2E-8771 & 15,63 & 33,50 & 16,45 & 4,12 & NP & 29,35 & 0,49 \\
\hline
\end{tabular}

2 
Figure 2 (on next page)

Samples (Feathers and fish)

Figure 2. Fossilized feathers and fish of the Santana Formation. (A) GP/2E-8771; (B) GP/2E7854; (C) GP/2E-7853; (D) Detail of the barbs and barbules of GP/2E-8771; (E) Detail of the barbs and barbules of GP/2E-7854. Arrows indicate the barbules. (F) Photograph of the the umbilicus proximallis; (G) Interpretative drawing of the calamus; (H-I) The GP/2E-7853 specimen; (I) Detail of the Dastilbe sp. fossil fish. Legend of (G): CL - Calamus; BI - Isolated Barb; VX - Vexillum (vanes); RQ - Rachis. Scale bars: (A, C, F-G) 2 mm; (B) 5 mm; (C) 2 mm; (D, H-I) $10 \mathrm{~mm}$; (E) $1 \mathrm{~mm}$ (F) Detail: 2,6 mm. 

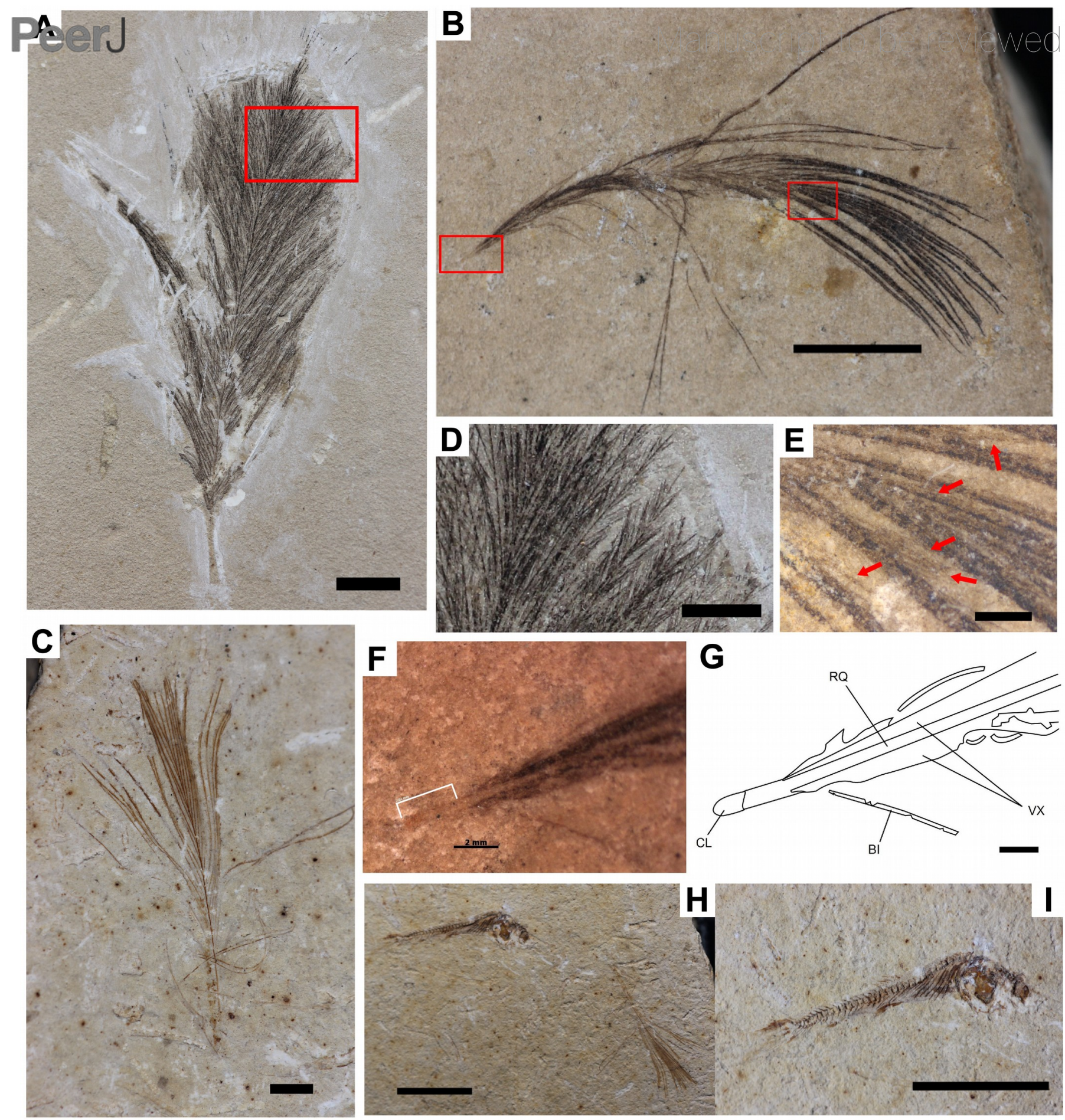


\section{Table 3(on next page)}

Feather portions calculation

Table 3. Difference in percentage between portions of the feathers compared to the maximum length. Legend: ND - No data available. 


\begin{tabular}{c|c|c|c}
\hline \multirow{2}{*}{ STRUCTURE } & \multicolumn{3}{c}{ PERCENTAGE } \\
\cline { 2 - 4 } & GP/2E-7853 & GP/2E-7854 & GP/2E-8771 \\
\hline Larger barb & 46,41 & 6,16 & 50,90 \\
Minor barb & 69,95 & 77,37 & 87,70 \\
Calamus & ND & 1,26 & ND \\
Rachis & 41,57 & 36,68 & 12,39 \\
\hline
\end{tabular}




\section{Table 4(on next page)}

Taxonomic assignment

Table 4. Classification of the described feathers. 
1

\begin{tabular}{cccc}
\hline SPECIMEN & MORPHOTYPE & $\begin{array}{c}\text { EVOLUTIONARY- } \\
\text { DEVELOPMENTAL MODEL }\end{array}$ & $\begin{array}{c}\text { MORPHOTYPE MODEL PRESENT } \\
\text { OF THE FOSSIL RECORD }\end{array}$ \\
\hline GP/2E-7853 & Downy feathers & IIIb & Morphotype 4 \\
GP $/ 2$ E-7854 & & IIIa + b & Morphotype 6 \\
GP $/ 2$ E- 8771 & Semiplume (Contour feather) & \\
\hline
\end{tabular}

2 